\title{
Immigration within the European Union Increases Support for Eurosceptic Parties
}

\author{
Dimiter Toshkov ${ }^{1}$ \\ Institute of Public Administration, Leiden University, the Netherlands
}

This version: 14 April 2021

\begin{abstract}
What are the political consequences of immigration? Theoretically, the mechanisms of intergroup contact and outgroup threat can lead to contradictory effects, and it remains uncertain which one would prevail in different contexts. In this article I study the impact of immigration from Central and Eastern Europe (CEE) on support for Eurosceptic parties between 2004 and 2019 in the Netherlands, Denmark, Sweden, Finland, Italy and Portugal. I find that higher levels of immigration from CEE are systematically related to higher voting shares cast for right-wing Eurosceptic parties at the local level in all of these countries, net of the influence of non-Western immigration. In most countries, the effects are also robust to including a rich set of local-level socio-economic controls. These effects can be found in elections for the European Parliament as well as in national elections. The effects have not diminished over the past 15 years and are most visible in mid-sized localities. The effect on left-wing Euroscepticism is positive in the Netherlands, but negative in Denmark, Sweden and Italy. These results highlight the tension between free movement and political support for European integration. Even in the European Union, immigration from other member states can trigger hostile political reactions.
\end{abstract}

\section{Keywords}

contact hypothesis, Eastern Europe, European integration, Euroscepticism, immigration, labor migration, voting

${ }^{1}$ Corresponding author: d.d.toshkov@,fgga.leidenuniv.nl ORCID: 0000-0002-7444-9340. 


\section{Introduction}

Modern states erected significant barriers to population movements within their territories and across their borders. But in Europe, the European Union (EU) gradually removed these barriers for its member states and provided for free movement of citizens of the Union (Schmidt, Blauberger, and Martinsen 2018). The opportunity for free movement and work led to significant cross-border migration, especially since the accession of the former communist countries from Central and Eastern Europe (CEE) in 2004 and 2007. Migration has well-recognized if difficult to estimate economic and social effects (Sequeira, Nunn, and Qian 2017; Borjas 2019), both for the receiving and the sending countries. But migration also has political effects, which we know much less about. Moreover, in the context of a multi-level system of governance such as the EU, migration can affect not only the politics of the member states, but the politics of the union itself.

This article examines the effect of intra-EU migration on support for Eurosceptic political parties. This political effect is highly significant, because it can undermine the course of European integration itself, in addition to disturbing the national politics of the EU member states. The surge of support for Eurosceptic parties across the EU since the beginning of the 2000s coincides in time with increasing intra-EU migration. In addition, we have solid evidence that at the individual level anti-immigration attitudes are strongly predictive of voting for Eurosceptic parties (i.a. Hobolt and de Vries 2016; Kentmen-Cin and Erisen 2017). We still lack systematic evidence, however, whether the arrival of immigrants from other EU states causes more anti-immigrant sentiments that increase support for Eurosceptic parties.

Indeed, in theory the presence of new immigrants can both attenuate anti-immigration attitudes of the host population through increased direct contact with the outgroup and it can bolster exclusionary and xenophobic attitudes through increases in perceived threat and competition. In the case of intra-EU migration, it is unclear which of these mechanisms will prevail. On the one hand, the cultural distance between immigrants from CEE and the host populations in Western Europe is relatively small, EU membership provides a strong legitimation of free movement, and more than 15 years have passed since the initial post-enlargement East-West migration flows. On the other hand, negative political discourses targeted at CEE immigrants in the West are still widespread and opportunities for direct contact with such immigrants have not been equally distributed across the territories of the host countries. All these different arguments leave the question about the impact of intra-EU migration on support for Eurosceptic parties open. 
Both the societal and theoretical importance of this question necessitate a more comprehensive empirical analysis than is currently available in the academic literature. Existing studies show that the local-level presence of Eastern Europeans was associated with lower levels of approval for the Constitutional Treaty of the EU at the referenda in the Netherlands, France, Ireland and Spain (Toshkov and Kortenska 2015). Country-level panel data also suggests that the presence of Eastern Europeans is positively associated with negative evaluations of the benefits of EU membership, and to a lesser extent, with lower trust in the EU (Jeannet 2020b). In addition, at the individual level, increasing numbers of CEE immigrants have been linked with increased perceptions of immigration as an economic threat (Jeannet 2020a). This study extends significantly the empirical scope of this literature and presents new theoretical ideas about how the effect of intra-EU immigration should vary over time, types of elections, varieties of Euroscepticism and size of localities.

For its theoretical contribution, the article develops hypotheses suggesting that the positive effect of intra-EU migration on support for Eurosceptic parties should be relevant of both left- and right-wing Euroscepticism, should be most visible in mid-sized localities, should diminish over time, and should be smaller in national vs. European elections.

For the empirical analyses, I collect and combine from different sources (a) local-level data on immigration presence disaggregated by country of origin, (b) election data, and (c) a number of demographic and socio-economic variables, for six countries from Western, Northern and Southern Europe: the Netherlands, Denmark, Sweden, Finland, Italy and Portugal. In total, the analyses cover 26 European and national elections. For each election, I regress the local-level share of the vote for right- and left-wing Eurosceptic parties on levels and changes in the local-level share of CEE immigrants from the population, levels of non-Western immigration, and a host of other social and economic variables that could potentially confound the relationships of interest.

I find that in almost all countries and elections in the sample, higher levels and increases in the local-level share of CEE immigrants are associated with higher levels of support for right-wing Eurosceptic parties, net of the socio-economic confounders. The effect on left-wing Euroscepticism is heterogeneous: positive in the Netherlands, but negative in Italy, Denmark and Sweden. In line with the theoretical predictions, this effect of immigration presence is greater in mid-sized localities than in small ones and more discernable than in very big ones. But contrary to the hypotheses, there is no evidence that the effect diminishes over time nor that it is systematically smaller in national vs. European elections. 
These results imply that the positive effect of direct contact between immigrants and host populations on immigration attitudes can be overwhelmed by the negative effect of threat and competition, even when the cultural distance between the in- and out-groups is small and opportunities for contact last a long time. The findings also suggest that the negative effect of intraEU migration on political support for the EU is anything by short-lived and it has spilled over from the European to the national electoral arenas as well.

The findings contribute to the emerging literature on the politics of place (Adler and Ansell 2019; Hopkins 2010) and show how the local demographic context interacts with national-level political discourses to influence support for European integration and increase the votes of right-wing Eurosceptic parties.

\section{Immigrants as an outgroup: contact, threat and competition}

\section{The contact bypothesis}

In most general terms, the research question that animates this study is about the effects of contact between in- and out-groups, with the CEE immigrants being the outgroup and the host populations in Western, Northern and Southern Europe where the immigrants arrive to work and settle being the ingroups. Intergroup contact and its effects have been studied extensively in different social science disciplines, including Sociology, Social Psychology, Economics and Political Science. A common point of departure of this scholarship is Gordon Allport's work (1954), which suggested that intergroup contact can reduce intergroup prejudice. The empirical evidence in favor of this so-called 'contact hypothesis' appears to be significant. A highly-cited meta-analysis (Pettigrew and Tropp 2006) claims strong support for the contact hypothesis and concludes that an 'interrelated bundle of conditions' can increase the negative effect of contact on prejudice even more. In another meta-analysis, the same authors find that contact reduces prejudices via reducing anxiety about intergroup contact, increasing empathy and, to a lesser extent, enhancing knowledge about the outgroup (Pettigrew and Tropp 2008). For anxiety to be reduced, direct and prolonged contact is typically needed, for example in the form of intergroup friendships. Extending this meta-analysis, Green and Green (2019) point out that contact's effects vary significantly with context.

\section{Outgroup threat}

When the presence of an outgroup becomes more visible and salient, but there is no direct contact, the threat from the outgroup can increase exclusionary attitudes instead of decreasing prejudice. In a 
randomized controlled trial, Enos (2014) placed Spanish-speaking confederates at commuter train stations in homogenously-Anglo-white communities in the US every day for two weeks. This randomized intervention led to significant increases in support for exclusionary immigration policies among the local commuters. Importantly, these effects became smaller with longer exposure to the outgroup. Conversely, in a randomized study of Norwegian army conscripts, contact with immigrants was found to decrease negative stereotypes, but not views on whether immigrations makes the country a better place to live (Finseraas and Kotsadam 2017).

In an attempt to reconcile such divergent findings, MacInnis and Page-Gould (2015) propose that intergroup interactions (which are indirect and fleeting) can increase intergroup bias, stress, anxiety and outgroup avoidance, while (direct and sustained) contact might have the opposite effects. Feelings of threat from an outgroup can arise from expectations about economic and social competition, but they can also be based on lacking familiarity and fear of cultural and value conflicts (Schneider 2008). Even distant but realistic threats can activate local threats that can fuel intolerance (Bouman, van Zomeren, and Otten 2015). Narratives of threat that reinforce stereotypes about migrants can influence in a major way perceptions of migrants and support for restrictive policies (Stansfield and Stone 2018).

\section{Outgroup size and its effects at different scales}

Individual intergroup interactions and contact scale in a complex way, so that in spatially-aggregated data the relationship between outgroup presence and social outcomes of interest depends on the exact level of aggregation. For example, the negative effect of ethnic segregation on social trust of immigrants is particularly strong in neighbourhoods with small minority populations (Ziller and Spörlein 2020). Kros and Hewstone (2020) find that negative interethnic contact is not related to ethnic neighborhood composition, but positive contact is. More ethnic minority members in the neighborhood provide more opportunities for intergroup contact and the reduction of prejudice it brings (Wagner et al. 2006).

At higher levels of aggregation, however, the total effects might change. Examining a relatively long time-period (1988-200), Semyonov et al. (2006) conclude that 'anti-foreigner sentiment tends to be more pronounced in places with a large proportion of foreign populations'. Relatedly, Scheepers et al. (2002) find that 'people living in individual competitive conditions perceive ethnic outgroups as a threat, and that this in turn reinforces ethnic exclusionism'. Perceptions of threatened group interests were higher when the outgroup size was 
perceived as larger, which in turn corresponded with objective measurements (Schlüter and Scheepers 2010).

In a longitudinal survey in three European countries, Binder et al. (2009) find reciprocal effects between contact and prejudice and establish that contact effects are mediated by intergroup anxiety. According to McLaren et al. (2021), growing up in place with a diverse population is related to positive immigration attitudes, especially when income inequality is low. McLaren (2003) concludes that intimate contact with minority groups can reduce anti-immigration policy preferences and that such contact reduces perceived threat when immigration levels are high. A study in Belgium also finds that the perceived size of immigrant group has a stronger association with anti-immigration attitudes than actual immigration presence (Hooghe and de Vroome 2015). A recent comparative analysis of the European countries included in the 2014 European Social Survey reaches a similar conclusion (Gorodzeisky and Semyonov 2020).

An increase in 'foreign populations is associated with higher political distrust amongst individuals who have anti-immigration attitudes', also according to Jeannet (2020c). Yet, studies that look at highly aggregated regional data find a positive association between levels and increases in total immigration and favourable immigration attitudes (Hoxhaj and Zuccotti 2021; Van Hauwaert and English 2019). In a meta-analysis, Stockemer et al. (2018) conclude that negative attitudes towards immigration are related to higher levels of Euroscepticism but that actual levels of immigration are not (see also Amengay and Stockemer 2019). Stockemer (2016) argues that individual perceptions of levels of immigration are positively related to higher support for radical right-wing parties, but the number of foreign-born citizens is not. However, in this study immigration levels are measured at the level of NUTS-1 and NUTS-2, which is too high to detect the effects of the local presence of specific group of immigrants.

\section{More on perceived and actual outgroup size}

It is also plausible that the numbers that people provide as estimates of the foreign-born population ('perceptions') are as much expressions of pre-existing attitudes towards immigrants as they are rational calculations of the share of immigrants in society. It has been shown that providing information can correct mis-perceptions about immigration, but information about the size of the foreign-born population is not enough to change policy views, with mixed evidence about effects on anti-immigration attitudes (Grigorieff, Roth, and Ubfal 2020; Hopkins, Sides, and Citrin 2019). A recent study focused on Europe finds that overestimation of the immigrant population fosters hostility against solidarity measures (Basile and Olmastroni 2020). But a carefully-designed study from 
Denmark concludes that while correct information can make participants change their reported factual beliefs about outgroup size, this information is reinterpreted 'in a highly selective fashion, ultimately failing to change their policy preference' (Jørgensen and Osmundsen 2020). People also tend to underestimate the share of immigrants with preferred characteristics (Zhirkov 2021), and learning from facts in this domain is politically motivated, especially for those with strong negative prior attitudes towards migrants (Glinitzer, Gummer, and Wagner 2021).

\section{The moderating effect of political ideology}

While in general intergroup contact may be associated with less opposition to immigration, political ideology might be moderating this association, so that the positive effect does not work to the same extent for people with right-wing political ideology (Thomsen and Rafiqi 2019). At the personal level, both right-wing authoritarianism and social dominance orientation are systematically related with prejudice and opposition to immigrants (Duckitt and Sibley 2010). Partisan affinities might moderate the effect of contact with immigrants, reducing threat only among leftist voters (Homola and Tavits 2018). Relatedly, Thomsen and Rafiqi (2020) find that the link between social trust and outgroup threat is stronger for those on the left of the political spectrum. According to Goodman, 'immigration threats are filtered through partisanship in polarized settings' (Goodman 2021).

\section{Economic conditions and anti-immigration sentiments}

There is not much evidence that economic conditions influence significantly the link between outgroup presence and social attitudes. Kuntz et al. find that changes in objective economic conditions are not related to anti-immigrant sentiments (but perceptions of these conditions are) (Kuntz, Davidov, and Semyonov 2017; see also Boateng et al. 2021).

\section{Contact, threat and refugees}

Direct exposure to one particular outgroup - refugees and asylum-seekers - has been studied extensively. It has been shown to induce hostility towards different groups of migrants and minorities, to increase support for restrictive asylum and immigration policies in Greece (Hangartner et al. 2019), to increase support for the far right in in Denmark (Dustmann, Vasiljeva, and Piil Damm 2019), in Austria (Steinmayr 2020), and in Hungary (Gessler, Tóth, and Wachs 2021). At the country level, 'greater ethnic diversity is associated with decreased support for refugees', but the effect depends on the measure of diversity used (Steele and Abdelaaty 2019, 1833). De Coninck et al. (2020) argue that interethnic 
contact is positively related to attitudes towards refugees, but their research design leaves open the possibility of self-selection into contact. In a carefully-executed study in Eastern Germany, Schaub et al. find no effects of local exposure to refugees on average voting and attitudes, but they note a convergence of right- and left-leaning individuals towards the center (Schaub, Gereke, and Baldassarri 2020).

It might be the valence of contact rather than frequency that is important. In Turkey, the massive inflow of refugees from Syria did not affect support for the governing APK party (Altındağ and Kaushal 2021). The number of asylum-seekers and the media attention they receive have been shown to affect Euroscepticism and attitudes towards national political institutions (Harteveld et al. 2018). Van der Brug and Harteveld find that increases in the number of asylum applications lead to a polarization of attitudes towards immigrants between left-and right-leaning citizens' in Western Europe, but not in Southern and Eastern Europe (van der Brug and Harteveld 2021).

Relatedly, Brosius et al. (2019) conclude that trust in the EU is affected by the media coverage of immigration and refugees and that the link between immigration attitudes and trust in the EU becomes stronger as the salience of immigration increases in the course of the refugee crisis. The importance of media is also underscored by the study of Blinder and Jeannet (2018) who show that different depictions of migrants in the media can shift public perceptions of immigration in terms of its size and composition.

\section{Effects on social preferences}

Perceived ethnic threats can decrease support for some welfare programs, such as social assistance, but not others that are perceived to benefit natives, such as pensions, as well as drive support from the left to the radical right-wing parties (Arndt and Thomsen 2019).

Adopting a within-country between-regions design, Alesina et al. (2021) find that 'native respondents display lower support for redistribution when the share of immigrants in their residence region is higher.' Importantly, this negative association is stronger for immigrants from the Middle East and Eastern Europe and is not significant for immigrants from EU-15 or sub-Saharan Africa (Alesina, Murard, and Rapoport 2021).

\section{Effects of immigration on support for radical right parties}

There are several studies that find links between support for radical right parties and immigration (for an overview, see Guriev and Papaioannou 2020). Unsurprisingly, at the individual level, anti- 
immigration attitudes are strongly related to the likelihood of supporting radical right parties, for many of which anti-immigration rhetorical is a central part of their message. But it might not be a change in anti-immigration attitudes as such that drives support for the radical right, but an increase in the salience of immigration that activates pre-existing opposition to immigration (Dennison and Geddes 2019). Relatedly, Damstra et al. (2021) find that in the Netherlands the volume of immigration news increased support for anti-immigrant parties. But salience and media coverage cannot be taken as completely exogenous to the concerns that higher immigration levels and changes in the composition of arrivals bring to the host populations.

McDonnell and Werner (2019) argue that across six European countries the supporters of radical right parties were closer to their parties with respect to their policy positions on immigration compared to their positions on European integration. It is uncertain whether immigration and unemployment interact in affecting support for radical right parties (Sipma and Lubbers 2020).

At the aggregate level, the evidence for links between immigration presence and support for the radical right is mixed. Rydgren and Ruth (2013) find that in Sweden support for the radical right increases in areas close to immigrant-dense areas, but not within these areas. In Austria, local voting for the FVÖ has increased as an effect of the inflow of immigrants into a community (Halla, Wagner, and Zweimüller 2017). One study of Finland finds that increases in the share of foreign citizens in a municipality decreases the votes for the Finns Party (note, however, that all foreigners are considered) (Lonsky 2021). In the UK membership of the British National Party is higher in highly-segregated cities with a larger proportion of non-whites (Biggs and Knauss 2012).

In France, immigration increased support for far-right (and to a smaller extent to far-left) candidates at presidential elections between 1988 and 2017 (Edo et al. 2019). Bolet also finds that in places with high local unemployment rate, the presence of immigrants and the labour market competition it engenders increase the vote share of the radical right (Bolet 2020). Evans and Ivaldi report a curvilinear 'halo effect': the vote for the radical right in 2017 increased in areas 'surrounding communities with significantly higher-than-average immigrant populations' (J. Evans and Ivaldi 2020). An older study from 2013 also concludes that the link between the votes for the French Front National and immigration presence depends on the level of analysis (Della Posta 2013).

In the Netherlands, support for the radical right PVV is found to be high in areas with low shares of minorities (up to a tipping point) (van Wijk, Bolt, and Tolsma 2020; van Wijk, Bolt, and Johnston 2019). Importantly, the authors find that "In urban areas, native residents of relatively homogenous neighbourhoods whose surrounding area - the 'balo' - harbours a pronounced cluster of minority residents are more likely 
to support the radical right." This is consistent with the idea that direct contact might decrease antiimmigration attitudes and support for anti-immigration policies and parties, but indirect 'interactions' and the local-level presence of an outgroup can have the opposite effects. At the same, at the very low-aggregation level of neighbourhoods, an increase in the proportion of (non-Western) immigrant residents is associated with more positive views on immigrants among natives (van Heerden and Ruedin 2017), but this association could be due to reversed causality. Using panel public opinion data, (Savelkoul, Laméris, and Tolsma 2017) find that 'ethnic minority density is positively related to the likelihood to vote for the PVV', especially when 'the size of the minority group exceeds 15 per cent of the total neighbourhood population'. Janssen et al. underscore the importance of aggregation scale for such studies: they find that at the micro scale (100 by 100 meter grids) 'the presence of nonWestern minorities is related to less anti-immigrant attitudes' but at higher scales, up to a municipality, support for the PVV increases, even if anti-immigrant attitudes or political dissatisfaction do not (note that the authors only look at non-Western immigrants, however).

Overall, while the importance of anti-immigration attitudes as predictors of voting for the radical right might have increased over time (Abou-Chadi, Cohen, and Wagner 2021), such attitudes are still not a necessary condition for voting for such parties, with one-third of their voters having no concerns over immigration (Stockemer, Halikiopoulou, and Vlandas 2020). For the voters that have such concerns, both cultural and economic grievances are important for supporting the radical right (Halikiopoulou and Vlandas 2020); for the UK, see (Hix, Kaufmann, and Leeper 2021). This is why when the economic and cultural differences between the host populations and the immigrants are larger, support for the radical right really grows (Shehaj, Shin, and Inglehart 2019).

\section{Effects of immigration on Euroscepticism}

There is strong and uncontroversial evidence that at the individual level anti-immigration attitudes are related to opposition to European integration (Hobolt and de Vries 2016; Kentmen-Cin and Erisen 2017; Boehmelt and Bove 2020; de Vreese and Boomgaarden 2005) and EU enlargement (Azrout, van Spanje, and de Vreese 2013). But there is much less evidence that immigration presence and increases in immigration drive Euroscepticism (Toshkov and Kortenska 2015; Jeannet 2020b; 2020c; Barbulescu and Beaudonnet 2014).

In the UK, support for the Eurosceptic right-wing party UKIP has been shown to be related to anti-immigration attitudes (Clarke et al. 2016). While British regions with high levels of immigration had some of the lowest levels of support for Brexit at the 2016 referendum, perceived immigration 
levels were associated with greater Euroscepticism, contrary to self-reported actual contact with immigrants (Palma, Sinclair, and Esses 2020). According to Meleady et al. (2017) anti-immigrant prejudice was highly predictive of voting to leave the EU and was fueled by negative intergroup contact. The increasing association between the issues of immigration and Euroscepticism has contributed to the emergence of a new dimension of party competition, with UKIP the main beneficiary (G. Evans and Mellon 2019). There is some evidence that in the UK the presence of Poles was associated with higher support to leave the EU (Viskanic 2017) (but see Becker, Fetzer, and Novy 2017).

Studies of attitudes towards free movement in the EU find that the sentiment and framing of the issue by the media (e.g. in terms of labour market or security) can have an influence that varies, however, strongly in different countries (Meltzer et al. 2020). Lutz (2021) concludes that support for free movement depends on the relative salience of inward and outward mobility. According to Vasilopoulou and Talving (2019), people with strong national identity are more likely to oppose intraEU migration (see also Blinder and Markaki 2019), but only in richer member states.

\section{Immigrant characteristics}

The majority of these results for the effects of immigration on anti-immigration attitudes and voting for populist radical right parties consider the group of immigrants as a whole. But the literature shows that immigrant characteristics matter significantly for the evaluation of the desirability of different immigration groups and the perceived threat that they pose. Europeans prefer immigrants (asylumseekers in particular) who have higher employability, severe vulnerabilities and are Christian (Bansak, Hainmueller, and Hangartner 2016). Hence, both cultural proximity (based on religion) and deservingness (based on the vulnerabilities) affect the judgements. Similarly, evidence from Denmark and Germany shows that highly skilled immigrants are preferred (Fietkau and Hansen 2018). With regard to the labour market competition hypothesis, research in the US shows that 'both low-skilled and highly skilled natives strongly prefer highly skilled immigrants over low-skilled immigrants, and this preference is not decreasing in natives' skill levels' (Hainmueler and Hiscox 2010). Yet, adding an ethnic descriptor lowers support (España-Nájera and Vera 2020).

How the outgroup is framed in media and popular discourse matters as well. De Coninck (2020) finds that people are more positive towards 'refugees' rather than 'immigrants', imigratns with the same ethnicity, from 'rich' countries, and from European countries (but Eastern Europeans are not separated). Even other migrants perceived newcomers as benefiting more from the welfare states 
of the host societies than the contribute, and more so if they happen to come from Eastern Europe or from poor countries outside Europe (Hedegaard and Bekhuis 2021). Group cues work by triggering anxiety, as a study of Latino vs. European migrants in the US shows (Brader, Valentino, and Suhay 2008).

Media coverage of immigration is often negative, but the frames used for different migrant groups still differ (Eberl et al. 2018), and the framing can change people's attitudes 'not matter their level of cognitive engagement' (Wenzel and Żerkowska-Balas 2019). Populist messages can also increase negative feeling towards migrants for supporters of populist parties, even if they fail to change people's minds about the social consequences of immigration (Rooduijn, Bonikowski, and Parlevliet 2021).

There are documented differences in discourses on free movement: for example, freedom of movement did not become a major political concern in Germany, but it did in the UK (Roos 2019). For the Netherlands, van Ostaijen (2020) reveals the existence of 'a European legal discourse legitimated by expert authorization which differs with a Dutch national discourse legitimated by mythopoesis'. Yet when it comes to policy effects, despite the overall negative rhetoric, there is little evidence that the welfare states in Western Europe have retrenched in response to free movement (Kramer, Sampson Thierry, and van Hooren 2018).

\section{Intra-EU immigration and support for Eurosceptic parties: Theoretical hypotheses}

The review of existing literature established that there are multiple plausible mechanisms through which increasing presence of an outgroup, such as immigrants, can affect the political attitudes and behavior of the local population. In this section of the article, I develop theoretical hypotheses based on these mechanisms that are calibrated to the case of intra-EU migration following the EU enlargement to the East and its impact on support for Eurosceptic political parties.

Overall, the mechanisms of threat and competition for economic and other resources provide enough reasons to expect that CEE immigration could have increased support for Eurosceptic parties. While direct contact could reverse these effects, it is possible that the frequency and intensity of contact between CEE immigrants and the locals are not sufficient to overwhelm the effects of threat and competition. The local-level presence of CEE immigrants can be salient and 'immediate' enough to provoke cultural and economic anxieties without being close enough to generate the positive effects of contact, which come from forming friendships and affective ties between the in- and out-group. Higher levels and increases in CEE immigration at the local level then provoke anti-immigration 
sentiments that lead to negative attitudes towards European integration, as the EU is the enabler of free movement that allows for the growth in CEE immigration. Anti-EU attitudes then increase electoral support for political parties that endorse Eurosceptic positions.

Hypothesis 1: Higher levels and increases in the share of CEE immigrants from the local population lead to higher levels of electoral support for Eurosceptic parties.

Note that this hypothesis refers to local level immigration shares. The level of aggregation is crucial, because at too low levels of aggregation (very small localities), the effects of direct contact can dominate the effects of threat, and at too high levels of aggregation (very big localities) macro-level factors become more important and multiple local-level effects of immigration get bundled together. The ideal level of aggregation to detect the hypothesized effect would be a locality with a total population between a few thousands and a few tens of thousands, but the choice of the level of analysis is very much constrained by data limitations. Nevertheless, we would expect that the effect of CEE immigration on Euroscepticism is greatest within this, not very precisely defined, population range.

Hypothesis 2: The effect of CEE immigration on support for Eurosceptic parties is most pronounced in localities between 10,000 and 100,000 people.

On the differences in attitudes towards immigrants and Euroscepticism between large cities, other urban and rural areas, see (Huijsmans et al. 2021). In short, the article finds that in the Netherlands large cities are outliers, having populations that are less Eurosceptic and more immigration friendly. Moreover, the differences between large cities and other areas (especially rural) have grown over time.

Existing evidence suggests that the effects of outgroup threat diminish over time with increasing familiarity with the outgroup, which decreases anxiety and presents opportunities for learning about the outgroup, even when direct contact remains limited. As the first significant increases in immigration from CEE happened around the time of enlargement of these countries to the EU (starting in 2004), a significant amount of time has passed already that should have provided opportunities for the host populations to get to know to new immigrants as a group. Moreover, the cultural distance between Eastern Europeans and Western Europeans can be considered relatively small, compared to, say, asylum-seekers from Afghanistan or labour migrants from rural China. Therefore, the increasing familiarity that comes with time could significantly reduce cultural anxiety. 
The legitimation of free movement by the EU institutions and pro-European political parties (to the extent that it exists in the West) would work in a similar direction.

Hypothesis 3: The effect of CEE immigration on support for Eurosceptic parties has declined over times since the mid 2000s.

Whether and how CEE immigration gets to influence politics and support for different parties depends on the national context as well. Media and political parties can increase the salience of immigration from this particular group and promote narratives that can fuel economic and cultural anxieties based on fear. In some countries, the political discourse on immigration can be dominated by discussion of other immigrant groups, such as asylum-seekers or irregular migrants. In addition, political actors can openly engage in negative stereotyping of Eastern Europeans and challenge the rationale of free movement in the EU.

In many European countries, Euroscepticism exists both on the left as well as on the right of the political-ideological spectrum. Right-wing Euroscepticism exploits cultural anxieties from immigration, while left-wing Euroscepticism is more concerned with economic ones. For example, van Elsas et al. (2016) find that left-wing Euroscepticism is motivated by economic and cultural concerns while only the latter is relevant for right-wing opposition to the EU. Both of these types of concerns can be related to immigration, although via different mechanisms.

In the context of intra-EU migration, right-wing Eurosceptic parties emphasize not only the economic threat posed by low-skilled immigrants from CEE and their impact of national welfare systems, but also threats related to crime, loss of national identity and values. Left-wing Eurosceptic parties are focused on economic effects, such as social dumping within the EU, increasing pressures on health, welfare and social services and the living conditions of immigrants. While the framing and salience of intra-EU migration differs on the left and on the right, there are plausible mechanisms that link both left- and right-wing Euroscepticism to rising immigration from within the EU.

Hypothesis 4: The effect of CEE immigration is present both for left-wing and for right-wing Eurosceptic parties. 
Because the arrival of Eastern Europeans is enabled by the process of European integration and the freedom of movement that membership in the EU provides, we would expect that the political effects are strongest when it comes to elections for the European Parliament (EP), which is the only EU institution for which the people vote directly. It has been argued that EP elections are second-order and electoral campaigns are dominated by national political issues. Moreover, national political parties in government can still exercise major influence over the details of EU policies, such as free movement and, of course, national heads of states and government still control the overall course of European integration via intergovernmental conferences and treaty changes. Therefore, it also makes sense for voters who want to limit intra-EU migration to vote at national elections for parties that oppose free movement. Still, to the extent that voters connect CEE immigration primarily to the EU, their political reactions should be most visible at EU-level elections.

Hypothesis 5: The effect of CEE immigration on support for Eurosceptic parties is greater at EP rather than national elections.

This set of five hypotheses is rooted in existing scholarship on intergroup interactions, but provides concrete and novel expectations about the effect on one important group of immigrants on one important aspect of political attitudes in Europe. The hypotheses predict variation across type of localities and elections, as well as over time. They also suggest that we examine both left- and rightwing varieties of Euroscepticism. To test these hypotheses, we need to compile data that is not readily available. The next section outlines the data collection strategy and the method of empirical analysis with which the theoretical hypotheses are tested.

\section{Research design, data and method of analysis}

Even though interactions between migrants and hosts occur at the individual level, the theoretical expectations are not at the individual, but at an aggregate level. The unit of analysis is referred to as $a$ locality, with the precise operationalization varying across countries due to data availability and administrative definitions.

The empirical analysis cannot proceed at the individual level for a number of reasons. First, the required data for a comprehensive, comparative study is not available: public opinion surveys of political preferences and immigration contact and attitudes very rarely isolate CEE immigrants into a separate group. Second, in methodological terms individual-level surveys face the problem of self- 
selection of respondents into contact with immigrants. Objective levels of immigration presence are not possible to establish for the respondents, and we know that subjective perceptions are tinted by the very attitudes of interest. Third, and most importantly, due to the multitude of countervailing mechanisms that can exist at the individual level, the relationships between the variables of interests can be different at the aggregate level from the most commonly encountered relationship at the individual level. That is, even if most individuals report lower slightly anti-immigration attitudes and support for Eurosceptic parties conditional on having close contacts with CEE immigrants, it could still be that at the aggregate level the presence of CEE immigrants has the opposite effects, if close contacts are rare and immigration presence without contact increases anti-immigration attitudes and Euroscepticism. Note that the fact that the design is at the aggregate level does not lead to the problem of ecological inference, because the inferences are also stated at that aggregate level, and not at the level of individuals. Table A1 in the Supplementary Material shows the exact level of analysis for each country and summary statistics of the population size of these localities.

The analyses are conducted within each of the countries in the sample separately. The data from different countries is not pooled together into a multilevel model for a methodological and a theoretical reason. In terms of methodology, the precise level of aggregation, variable definitions and set of confounders I control for in the statistical models differ across countries. In theoretical terms, the national-level political discourse is expected to affect not only the baseline level of support for Eurosceptic parties, but the relationship with immigration itself. Hence, while I compare the countrylevel inferences later in the analysis, this is not done directly via interactions in a multilevel model, which would be underpowered with the amount of countries and elections available.

The sample of countries included in the analysis consists of the Netherlands, Denmark, Sweden, Finland, Italy and Portugal. The criteria for inclusion are the country being a major destination for CEE immigrants since 2000, the existence of a Eurosceptic party competing at the EP elections and immigration data being available at the local level and disaggregated by country of origin or nationality of the immigrants. The CEE countries of emigration are not included, because the mechanisms through which migration affects Euroscepticism there are likely to be very different. The sample of included countries is diverse, featuring countries in Western Europe proper (the Netherlands), Southern Europe (Italy, Portugal) and Norther Europe (the three Scandinavian countries) that together account for a large share of all intra-EU immigrants from CEE since the early 2000s. Data over time is available for the Netherlands, Denmark, Finland, and Italy: for Sweden and Portugal we only have snapshots as of the latest EP elections in 2019 (see the overview in Table A2). 
CEE immigration is measured as the local-level share of CEE immigrants from the total number of people living in the locality. Wherever possible, I include in the CEE region the $11 \mathrm{EU}$ member states from CEE that joined in 2004 (Czechia, Hungary, Estonia, Latvia, Lithuania, Poland, Slovakia, Slovenia), 2007 (Bulgaria and Romania), and 2011 (Croatia). This measure varies between $0.16 \%$ and $8.82 \%$ with a mean of $1.23 \%$ in the Netherlands, between 0 and $5.15 \%$ with a mean of $2.11 \%$ in Denmark, between $0.53 \%$ and $7.13 \%$ with a mean of $2.41 \%$ in Sweden, between 0 and $12.73 \%$ with a mean of $0.64 \%$ in Finland, between 0 and $30 \%$ with a mean of $2.21 \%$ in Italy, and between 0 and $4.66 \%$ with a mean of $0.30 \%$ in Portugal (where only Romanians are counted).

I also employ alternative definitions that include other CEE countries that are not members of the EU, on the presumption that host populations are not very well informed about the exact status of these countries in the EU accession process. I take the natural logarithm of the share (adding one person to the immigration tally for localities with no CEE immigrants). See Table A3 for further details of the operationalization of the immigration presence variables.

The outcome variable of interest is measured as the local-level share of votes cast for Eurosceptic parties from all valid votes cast in the locality. To identify left- and right-wing Eurosceptic parties, I rely on party manifestos, media statements, membership of the EP transnational party groups and existing classifications and theoretical discussions (Heinisch, McDonnell, and Werner 2020; Halikiopoulou, Nanou, and Vasilopoulou 2012; Pirro, Taggart, and van Kessel 2018; van Elsas and van Der Brug 2015; van Elsas, Hakhverdian, and van der Brug 2016; Brack 2020). The definition of Euroscepticism is 'softer' than the most restrictive one that would only include parties that explicitly argue for a dissolution of the EU and a reversal of European integration, but 'harder' that the most inclusive one that would cover any party that is critical of any policy or institutions of the EU. In essence, the parties included have criticism of the EU close to the core of their electoral messages and focus on intra-EU migration in particular. The list of all parties that fall into the Eurosceptic category is available in Table A4.

Note that there is a very significant overlap between Eurosceptic, radical right (and to a lesser extent, radical left) and populist parties. While the theoretical interest is in support for Eurosceptic parties, there is an overlap in the mechanisms that would also produce support for radical and for populist parties. It is not a major objective of this article to separate the reasons for support for Eurosceptic, radical and populist parties, so this overlap is acknowledged but is not a methodological concern. 
At the 2019 EP elections, right-wing Eurosceptic parties gained on average (across municipalities) $15.24 \%$ of the valid votes in the Netherlands, $14.29 \%$ in Denmark, $19.40 \%$ in Sweden, 15.88\% in Finland, 45.60\% in Italy (including Lega), and 1.60\% in Portugal, but with great variation across localities. Left-wing Eurosceptic parties gained an average of 7.67\% in the Netherlands, 8.68\% in Denmark, $5.8 \%$ in Sweden and $15.72 \%$ in Italy.

In terms of confounders, the analyses feature a set of economic and social indicators that capture the current economic, social and demographic conditions in the locality. The precise set of controls and the variable definitions and data sources are described in details in Table A5. Importantly, I control in the models for levels of non-Western immigration. While these levels are often positively correlated with levels of CEE immigration, they diverge to a sufficient extent to allow the estimation of a separate effect of CEE immigration (the correlations between the shares of CEE and nonWestern immigrants from the local population at the municipal level are 0.34 in the Netherlands, 0.42 in Denmark, 0.34 in Sweden, 0.40 in Finland, 0.25 in Italy and 0.25 in Portugal). In addition to nonWestern immigration shares, the models control for the relative size of the locality (population, urbanization), economic conditions (unemployment, income), social conditions (social assistance, crime), social structure (shares of highly educated people and pensioners) and other variables that are important predictors of Eurosceptic voting in the country (religiosity, share of minority populations).

There are several methodological reasons that make it harder to find a relationship between CEE immigration and support for Eurosceptic parties, even if the relationship exists in reality. First, official immigration numbers capture only those who are officially registered, which is likely to underestimate the actual number of CEE immigrants and to miss precisely the type of people that are most likely to provoke fear and anxieties among the locals (those without official permanent address and a steady job). Second, CEE immigrants are likely to settle in more immigration-friendly localities, all things equal. I try to correct for this self-selection via the economic and social controls included in the models, but to the extent that it exists, this selection effect should bias downwards the estimate of the effect of immigration presence. Third, at the EP elections CEE immigrants are allowed to vote where they reside, and are likely to support pro-European parties when they do so, which would decrease the share of Eurosceptic voting cast by the host populations and mask an effect of immigration presence on Euroscepticism. Fourth, collinearity with non-Western immigration and the other covariates works to increase the standard errors of the effect estimates for CEE immigration presence. 


\section{Empirical results}

Figure 1 summarizes the main results from the empirical analysis. The figure shows the estimated coefficients and 95\% confidence intervals for the effects of CEE immigration presence on voting for right- and left-wing Eurosceptic parties at the 2019 EP elections. Positive coefficients imply that more immigrants from CEE at the local level are associated with greater voting shares for Eurosceptic parties. The details of the regression models on which Figure 1 is based are available Tables A6 and A7 in the Supplementary Material.

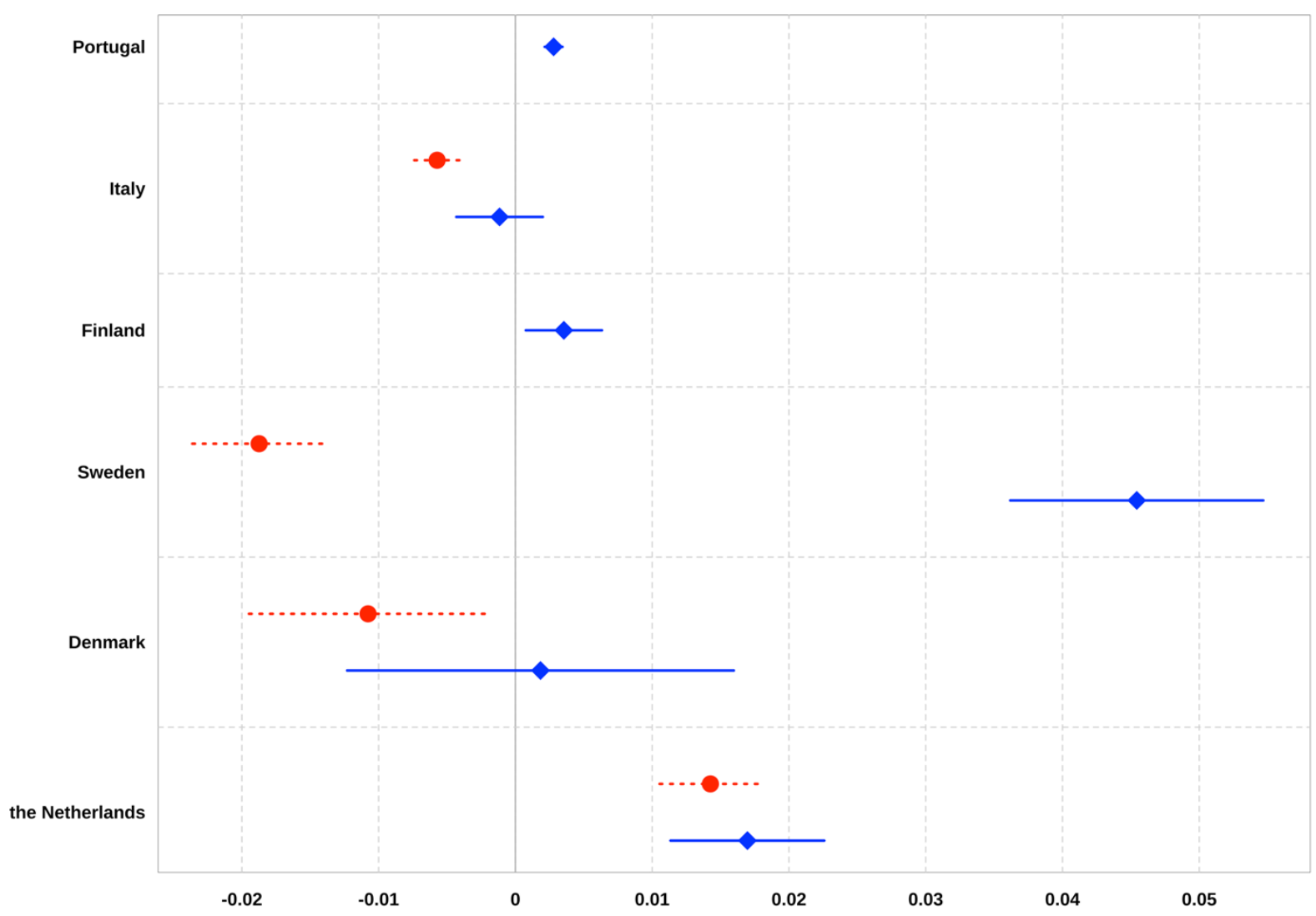

Figure 1. Coefficients and $95 \%$ confidence intervals for the effects of the (natural log of the) share of CEE immigrants from the local population on the vote shares of right-wing (blue) and left-wing (red) Eurosceptic parties at the 2019 EP elections

The effect of CEE immigration presence on the vote shares of right-wing Eurosceptic parties is positive in all countries with the exception of Italy, and it is statistically significant at the 0.05 level in all countries but Denmark and Italy. The effect on left-wing Euroscepticism varies: it is positive in the Netherlands but negative in Denmark, Sweden and Italy. In terms of substantive size, the importance 
of the effects differs across countries. Since the CEE immigration variable is log-transformed, the plotted coefficients show the expected effects for an increase of 2.7 of the CEE immigration share of the local population; for example, going from $1 \%$ to $2.7 \%$, or from $2 \%$ to $5.4 \%$. The size of the effects should be judged relative to the vote shares that the parties have received. The effect is rather big in Sweden, where the effect is comparable to the standard deviation of the right-wing Eurosceptic vote shares (which is 0.05), and it is moderate in the Netherlands, where the effect is smaller than half a standard deviation of the right-wing Eurosceptic vote shares (which is 0.04). Despite the small absolute size (0.003), the effect is also substantive in Portugal, where the standard deviation in the vote share for the Eurosceptic party is 0.0008 .

Even in Denmark and Italy we can find positive and statistically significant effect of CEE immigration presence on the vote share of right-wing Eurosceptic parties when we exclude the economic and social covariates from the models (see Table A8). This implies that in these countries the effect of CEE immigration is confounded by the socio-economic context or that part of the effect of immigration is exercised though changes in the local socio-economic conditions (e.g. higher crime or unemployment levels). When the full set of covariates are considered, the effects of CEE immigration presence on right-wing Euroscepticism in the Netherlands, Sweden, Finland and Portugal are robust to calculating the vote shares from all eligible voters rather than from the valid votes cast at the election (Table A9), to alternative definitions of Central and Eastern Europeans (with the exception of Finland, Table A10) and to calculating the change in CEE immigration shares between 2019 and 2004 rather than the 2019 levels (Table A11; Finland is an exception). In Italy, even with the full set of covariates there is a significant positive effect of CEE immigration presence on the vote share of Fratelli d'Italia - a strongly nationalistic and Eurosceptic party that has support that is less clustered regionally than the support of Lega, the other Italian party included in the share of right-wing Euroscepticism in the country (see Table A18).

All in all, we find considerable evidence in support of Hypothesis 1. When it comes to Hypothesis 4, however, only in the Netherlands there is evidence that CEE immigration presence is related with left-wing Euroscepticism. In fact, in Denmark, Sweden and Italy there is evidence for negative effects, meaning that higher relative shares of CEE immigrants at the local level are associated with fewer votes for such parties.

While we find evidence for relatively robust effects of CEE immigration presence - positive in the case of right-wing Euroscepticism and negative in the case of left-wing Euroscepticism, nonWestern immigration shares are not significantly associated with Eurosceptic voting in most of the 
countries included in this analysis. In Italy, non-Western immigration is positively associated with right-wing Euroscepticism and negatively with the left-wing variety. In Denmark, the effect of leftwing Euroscepticism is positive. In the other countries the effects are not robust (compare Tables A6 and A7 with A8).

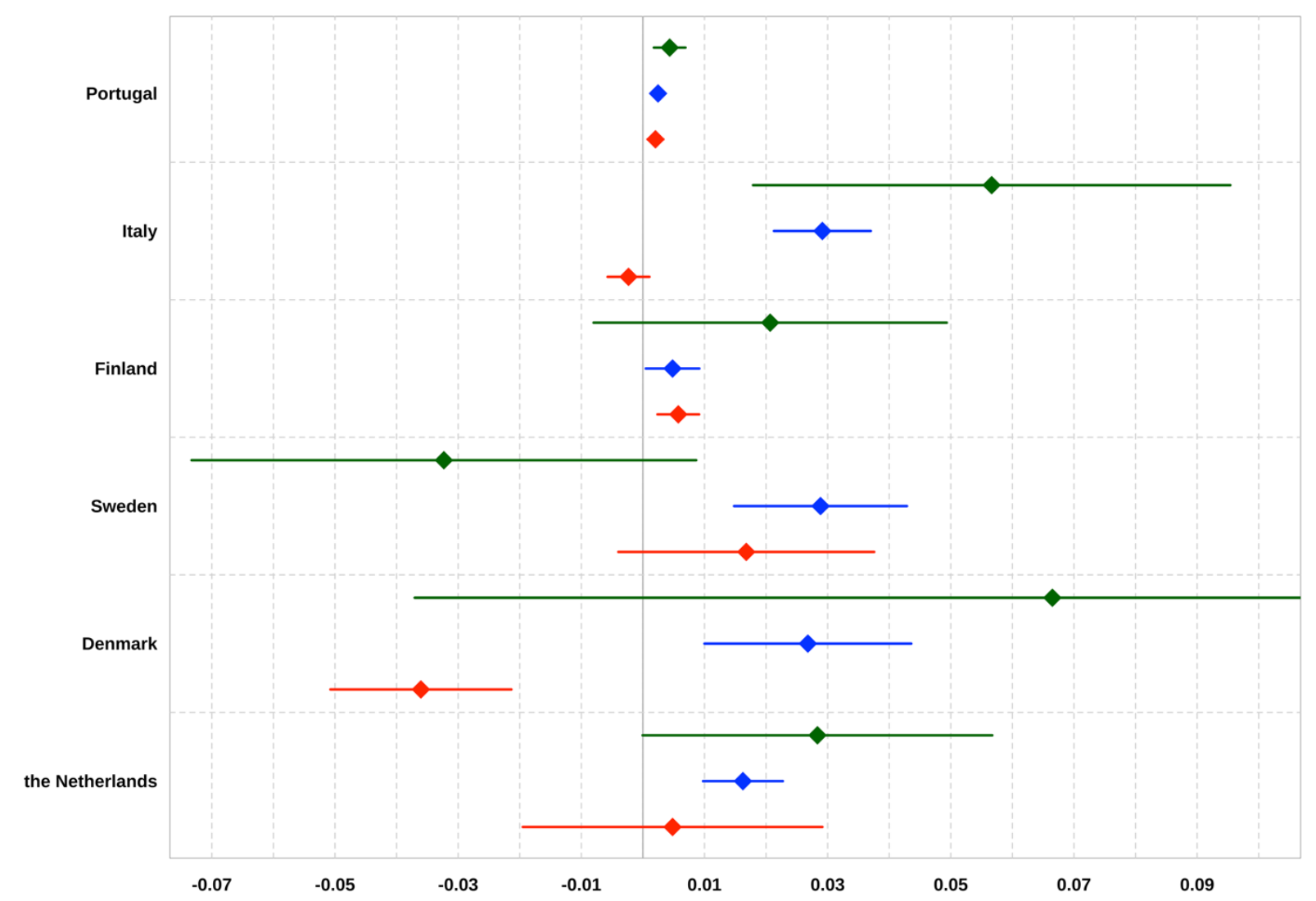

Figure 2. Coefficients and 95\% confidence intervals for the effects of the (natural log of the) share of CEE immigrants from the local population on the vote shares of right-wing Eurosceptic parties at the 2019 EP elections in small $(<10,000)$ [red], medium $(>10,000$ but $<100,000)$ [blue] and big $(>100,000)$ [dark green] localities

To examine Hypothesis 2, I classify the municipalities in each country in small, medium and big, using 10 thousand and 100 thousand as cut-off points. Figure 2 shows the effects of CEE immigration presence for these three different types of localities in each country. The estimates are based on simplified versions of the models reported in Table A6 and Figure 1, which only feature non-Western immigration as a covariate, due to the lower number of observations available, especially for the category of big municipalities. In accordance with the hypothesis, the effect of CEE immigration is smaller and, in most cases, insignificant in small localities (plotted in red). In Denmark the effect is even significant and negative. The effect is less precisely estimated in big compared to medium-sized 
localities, but this could be due to the lower number of observations available in that category. Altogether, there is mixed support for the hypothesis: while in small localities the positive effect of CEE immigration presence on immigration voting is indeed smaller or non-existent, the effect is not necessarily smaller - but it is more variable - in very big localities.

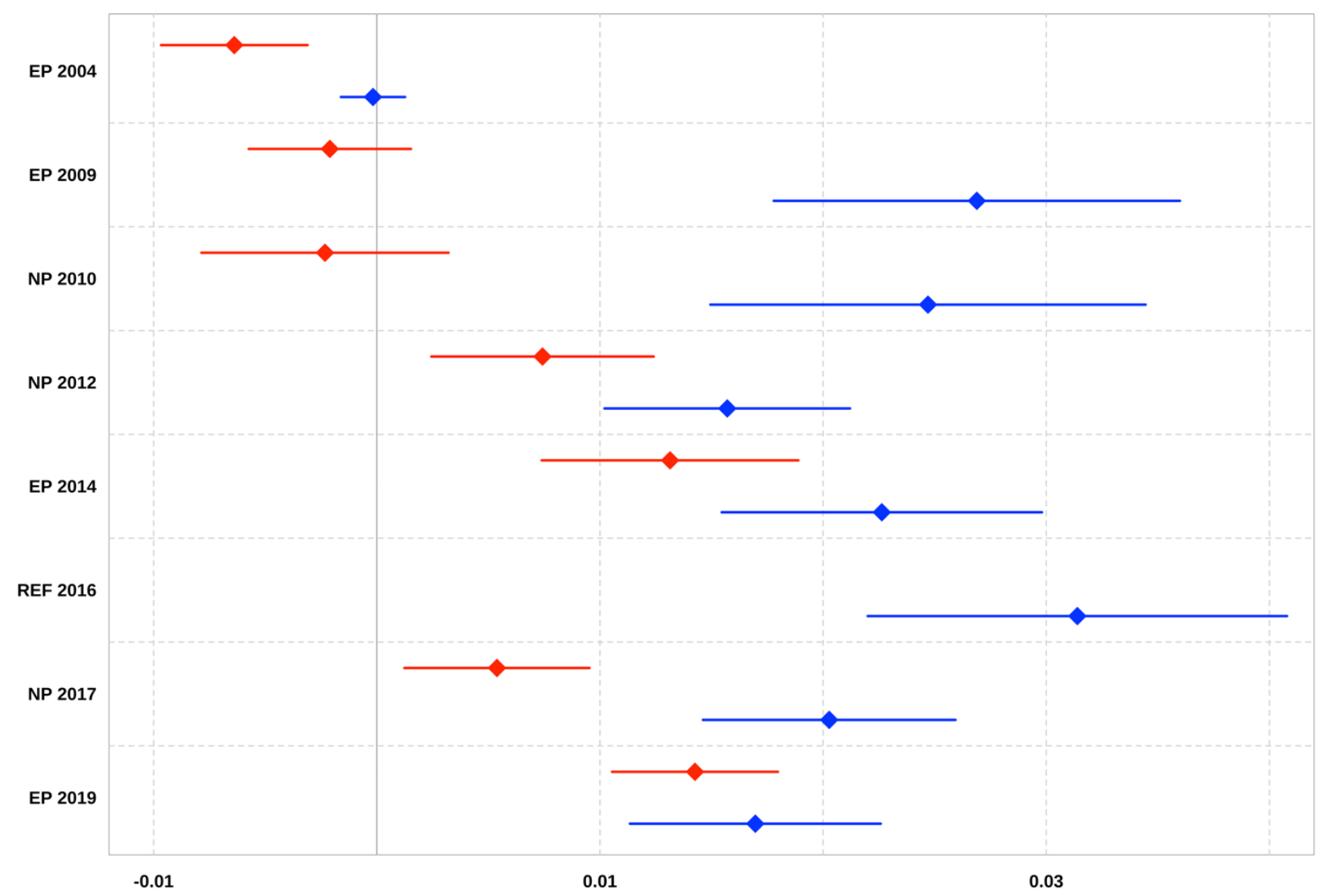

Figure 3. Coefficients and 95\% confidence intervals for the effects of the (natural log of the) share of CEE immigrants from the local population on the vote shares of right-wing (blue) and left-wing (red) Eurosceptic parties in the Netherlands at EP and national parliament (NP) elections and the share of votes at the 2017 referendum cast against the association agreement between Ukraine and the EU.

I examine Hypotheses 3 and 4 by focusing on the case of the Netherlands and looking at the past four EP elections since 2004, three national parliament elections, and the 2016 referendum on the association agreement between Ukraine and the EU. Figure 3 shows the estimated effects on rightand left-wing Eurosceptic voting. As the figure makes clear, the effects are present both for national and for EP elections, as well as for the referendum voting. The effects on right-wing Eurosceptic voting are greatest in 2009 and 2010, but they have not declined significantly since. The effect of leftwing Euroscepticism is visible only after 2012. The effects are not present in 2004, when the Eastern 
enlargement had just been concluded and the CEE immigration presence had not increased too much yet. The details of the regression models are in Tables A12 and A13.

In Finland, the pattern is similar, but the positive effect appears between the 2009 and 2014 EP elections (see Table A15) and between the 2011 and 2015 national elections (see Table A16). In Italy, the effect of CEE immigration presence on right-wing Eurosceptic voting increases till the 2019 EP elections and is actually significantly negative at the previous EP elections and at the national elections in 2018 (see Table A17). In Denmark, there is a similar development with the effect of CEE immigration presence on right-wing Eurosceptic voting becoming more positive, even if it is not significant in 2019, while the effect of non-Western immigration declines in size and switches signs.

Altogether, we have strong evidence to reject Hypothesis 3: the effect of CEE immigration presence does not diminish significantly, and in some countries, it actually becomes more positive. With regard to Hypothesis 4, we also do not find big differences between the effects of immigration on voting for Eurosceptic parties at national and at EP elections.

\section{Conclusion}

This study examined the political effects of immigration presence. Focusing on the impact that the arrival of migrants of CEE had on the voting preferences of the host populations in Western, Northern and Southern Europe, the article reported strong evidence that immigration contributed to the rise of right-wing Eurosceptic parties in the Netherlands, Sweden, Finland, Portugal, and possibly in Italy and Denmark as well. The effects are specific to CEE immigration and distinct from any possible influence of non-Western immigration. The relationship of CEE immigration presence (measured in levels and in changes) with voting for right-wing Eurosceptic parties does not diminish over time and is discernable in national as well as in EP elections.

These results have significant theoretical import. To remind, the findings are compatible with both mechanisms of contact and outgroup threat operating at the same time: the fact that we find no effects in small localities is consistent with an interpretation that contact can have positive effects on outgroup acceptance at a small scale, which however are overwhelmed by the negative effects of threat and competition in bigger places.

Free movement within the EU can be seen as a hard case for finding negative political effects

of immigration. After all, free movement, as a fundamental principle of European integration, is enshrined in the founding EU treaties and is supported by strong normative discourses. Moreover, the cultural distance between CEE migrants and the host populations is relatively small and a lot of 
time has passed since the first wave of mass East-West migration. Yet, even 15 years after the enlargement of the EU to the East, the negative political effects of CEE immigration are clearly visible in the voting data and show no signs of withering away. One potential explanation is that CEE immigrants are perceived as less deserving than people who are persecuted or come from poorer parts of the world. Another is the continuing negative framing of (labour) migration from the East in national media and political discourses in the West.

It is remarkable that the effect of immigration on Euroscepticism is found in all these rather different party-political systems and political contexts. This article significantly extended the empirical scope of the existing literature, which had already claimed similar effects of immigration on voting at EU-related referenda (Toshkov and Kortenska 2015), anti-immigration attitudes and EU trust (but at the country level) (Jeannet 2020b; 2020c), and support for radical right parties in Austria (Halla, Wagner, and Zweimüller 2017), France (Edo et al. 2019; Bolet 2020; J. Evans and Ivaldi 2020), and the UK (G. Evans and Mellon 2019). The evidence for effects in Southern Europe is particularly noteworthy, given long-held assumptions that this region is immune to Euroscepticism and the radical right. But this evidence fits recent findings about links between CEE immigration presence and voting for the radical right parties Vox at the regional elections in Andalucía in Spain (Toshkov 2018) and between the Roma minority and Chega! at the presidential elections in Portugal (Afonso 2021).

Yet, there are differences in how the effect plays out (cf. Denmark, where it is non-Western immigration that seems related with the radical right), especially when it comes to support left-wing Eurosceptic parties. This effect ranges from strongly positive in the Netherlands to strongly negative in Italy and Sweden. But left-wing Euroscepticism is a rather diffuse category with significant ideological and programmatic differences between the parties that are classified as such. Morevoer, negative discourse against CEE immigration can spill over throughout the political system. As Treib shows, claims about restricting migration from poorer countries in the EU occur in the election manifestos of center-right as well as radical right parties (Treib 2020). If mainstream and pro-European parties also endorse such views, they take the air out from the Eurosceptic parties on the fringes of the ideological spectrum, which weakens the relationship between CEE immigration shares and votes for Eurosceptic parties.

The results also contribute to the study of the politics of place and the 'geography of discontent' (Adler and Ansell 2019; Bolet 2021). In line with the hypothesis of politicized places, the differences found indicate that 'national and local conditions interact to construe immigrants as threatening' (Hopkins 2010, 40). In addition, this study shows that when we search for the impact of immigration, 
we should be careful to disaggregate the types of migrants we look at, because different categories of migrants might be associated with different effects. This might explain why the literature on the links between immigration presence and votes for radical right parties has produced divergent results.

The evidence presented in this article is consistent with studies at the individual level that find connections between EU support and anti-immigration preferences (i.a. Hobolt and de Vries 2016; Kentmen-Cin and Erisen 2017). But, importantly, it suggests that anti-immigration preferences themselves are rooted to some extent in developments in the real world and population changes at the local level in particular. People's perceptions (or at least what they tell pollsters) of national immigration levels might be far from the true levels, but at the margin, people's political choices seem responsive to the local conditions (Schlüter and Scheepers 2010). Hence, to some extent people's perceptions of the local immigration context must be grounded in reality (cf. Holbrook and Weinschenk 2020) - otherwise it is hard to explain how the true levels can be systematically related to relevant voting choices.

The conclusions of this article are consistent with historical evidence from the US that 'immigration triggered hostile political reactions, such as the election of more conservative legislators, higher support for anti-immigration legislation, and lower redistribution' (Tabellini 2020, 454). Similarly to the US, the discontent does not seem rooted in economic factors, but in cultural differences between immigrants and the host populations. Hence, the dynamic between immigration and political integration has broader historical relevance than the case of the EU. Any polity information faces the challenges of accommodating social mixing and making sure that this mixing does not derail the process of integration itself through political channels. In the words of Robert Putnam, In the short run ... immigration and ethnic diversity tend to reduce social solidarity and social capital.... In the long run, however, successful immigrant societies have overcome such fragmentation by creating new, cross-cutting forms of social solidarity and more encompassing identities' (Putnam 2007, 137). It remains a challenge for the EU to find such forms of social solidarities and identities that can counteract the political forces of Euroscepticism.

It will be worth extending the geographical scope of the current study to other major countries that received substantial numbers of CEE migrants (e.g. Germany, Spain) once the necessary data becomes available. But it will be even more interesting to study the political effects of CEE migration for the countries of origin of these population movements - the places that the migrants abandon. The social consequences of emigration can be just as great, and there are plausible mechanisms through which emigration can also increase distrust and resentment of the European Union among those literally left behind. 


\section{Acknowledgements}

I am grateful to the European University Institute (EUI) for a Jean Monnet visiting scholarship during which this project was developed. I would like to thank Elitsa Kortenska for input to earlier versions of this study, Alexandre Afonso for help with access to the Portuguese data, and the audiences at the Robert Schumann Centre for Advanced Studies and the Migration Policy Centre at the EUI and the VICES conference at the Free University Amsterdam for comments on earlier drafts of this article.

\section{References}

Abou-Chadi, Tarik, Denis Cohen, and Markus Wagner. 2021. "The Centre-Right versus the Radical Right: The Role of Migration Issues and Economic Grievances." Journal of Ethnic and Migration Studies, February, 1-19.

Adler, David, and Ben Ansell. 2019. "Housing and Populism." West European Politics 43 (2): 1-22. Afonso, Alexandre. 2021. "Correlates of Aggregate Support for the Radical Right in Portugal."

Alesina, Alberto, Elie Murard, and Hillel Rapoport. 2021. "Immigration and Preferences for Redistribution in Europe1." Journal of Economic Geography, March.

Allport, Gordon W. 1954. The Nature of Prejudice. Cambridge [etc.] Mass.: Addison-Wesley Publishing Company.

Altındağ, Onur, and Neeraj Kaushal. 2021. "Do Refugees Impact Voting Behavior in the Host Country? Evidence from Syrian Refugee Inflows to Turkey.” Public Choice 186 (1): 149-78.

Amengay, Abdelkarim, and Daniel Stockemer. 2019. “The Radical Right in Western Europe: A MetaAnalysis of Structural Factors.” Political Studies Review 17 (1): 30-40.

Arndt, Christoph, and Jens Peter Frølund Thomsen. 2019. "Ethnicity Coding Revisited: Right-Wing Parties as Catalysts for Mobilization Against Immigrant Welfare Rights." Scandinavian Political Studies 42 (2): 93-117.

Azrout, Rachid, Joost H P van Spanje, and Claes H de Vreese. 2013. "Focusing on Differences? Contextual Conditions and Anti-Immigrant Attitudes' Effects on Support for 'Turkey's EU Membership.” International Journal of Public Opinion Research 25 (4): 480-501.

Bansak, K, J Hainmueller, and D Hangartner. 2016. "How Economic, Humanitarian, and Religious Concerns Shape European Attitudes toward Asylum Seekers.” Science 354 (6309): 217-22.

Barbulescu, Roxana, and Laurie Beaudonnet. 2014. "Protecting Us, Protecting Europe? Public Concern about Immigration and Declining Support for European Integration in Italy." Perspectives on European Politics and Society 15 (2): 216-37. 
Basile, Linda, and Francesco Olmastroni. 2020. "Sharing the Burden in a Free Riders' Land: The EU Migration and Asylum Policy in the Views of Public Opinion and Politicians." European Journal of Political Research 59 (3): 669-91.

Becker, Sascha O, Thiemo Fetzer, and Dennis Novy. 2017. 'Who Voted for Brexit? A Comprehensive District-Level Analysis.” Economic Policy 32 (92): 601-50.

Biggs, Michael, and Steven Knauss. 2012. "Explaining Membership in the British National Party: A Multilevel Analysis of Contact and Threat." European Sociological Review 28 (5): 633-46.

Binder, Jens, Hanna Zagefka, Rupert Brown, Friedrich Funke, Thomas Kessler, Amelie Mummendey, Annemie Maquil, Stephanie Demoulin, and Jacques-Philippe Leyens. 2009. "Does Contact Reduce Prejudice or Does Prejudice Reduce Contact? A Longitudinal Test of the Contact Hypothesis Among Majority and Minority Groups in Three European Countries." Journal of Personality and Social Psychology 96 (4): 843-56.

Blinder, Scott, and Anne-Marie Jeannet. 2018. "The 'illegal' and the Skilled: Effects of Media Portrayals on Perceptions of Immigrants in Britain." Journal of Ethnic and Migration Studies 44 (9): 1444-62.

Blinder, Scott, and Yvonni Markaki. 2019. "Acceptable in the EU? Why Some Immigration Restrictionists Support European Union Mobility.” European Union Politics 20 (3): 468-91.

Boateng, Francis D, Wesley S McCann, Joselyne L Chenane, and Daniel K Pryce. 2021. "Perception of Immigrants in Europe: A Multilevel Assessment of Macrolevel Conditions." Social Science Quarterly 102 (1): 209-27.

Boehmelt, Tobias, and Vincenzo Bove. 2020. "Regional Integration Support: A Positive Externality toward Migration Attitudes.” Journal of Common Market Studies 58 (2): 309-27.

Bolet, Diane. 2020. "Local Labour Market Competition and Radical Right Voting: Evidence from France.” European Journal of Political Research, 6765.12378.

—. 2021. "Drinking Alone: Local Socio-Cultural Degradation and Radical Right Support—The Case of British Pub Closures.” Comparative Political Studies, March, 0010414021997158.

Borjas, George J. 2019. "Immigration and Economic Growth.” NBER Working Papers, no. 25836.

Bouman, Thijs, Martijn van Zomeren, and Sabine Otten. 2015. "When Threats Foreign Turn Domestic: Two Ways for Distant Realistic Intergroup Threats to Carry over into Local Intolerance." British Journal of Social Psychology 54 (3): 581-600.

Brack, Nathalie. 2020. "Towards a Unified Anti-Europe Narrative on the Right and Left? The Challenge of Euroscepticism in the 2019 European Elections." Research \& Politics 7 (2): 
2053168020952236.

Brader, Ted, Nicholas A Valentino, and Elizabeth Suhay. 2008. "What Triggers Public Opposition to Immigration? Anxiety, Group Cues, and Immigration Threat." American Journal of Political Science 52 (4): 959-78.

Brosius, Anna, Erika J van Elsas, and Claes H de Vreese. 2019. "How Media Shape Political Trust: News Coverage of Immigration and Its Effects on Trust in the European Union." European Union Politics 20 (3): 447-67.

Brug, Wouter van der, and Eelco Harteveld. 2021. "The Conditional Effects of the Refugee Crisis on Immigration Attitudes and Nationalism.” European Union Politics, February, 1465116520988905.

Clarke, Harold, Paul Whiteley, Walter Borges, David Sanders, and Marianne Stewart. 2016. "Modelling the Dynamics of Support for a Right-Wing Populist Party: The Case of UKIP.” Journal of Elections, Public Opinion and Parties 26 (2): 135-54.

Coninck, David De. 2020. "Migrant Categorizations and European Public Opinion: Diverging Attitudes towards Immigrants and Refugees.” Journal of Ethnic and Migration Studies 46 (9): 166786.

Coninck, David De, Isabel Rodriguez-de-Dios, and Leen D’Haenens. 2020. “The Contact Hypothesis during the European Refugee Crisis: Relating Quality and Quantity of (in)Direct Intergroup Contact to Attitudes towards Refugees." Group Processes \& Intergroup Relations.

Damstra, Alyt, Laura Jacobs, Mark Boukes, and Rens Vliegenthart. 2021. 'The Impact of Immigration News on Anti-Immigrant Party Support: Unpacking Agenda-Setting and Issue Ownership Effects over Time.” Journal of Elections, Public Opinion and Parties 31 (1): 97-118.

Dennison, James, and Andrew Geddes. 2019. "A Rising Tide? The Salience of Immigration and the Rise of Anti-Immigration Political Parties in Western Europe.” The Political Quarterly 90 (1): 10716.

Duckitt, John, and Chris G Sibley. 2010. "Right-Wing Authoritarianism and Social Dominance Orientation Differentially Moderate Intergroup Effects on Prejudice." European Journal of Personality 24 (7): 583-601.

Dustmann, Christian, Kristine Vasiljeva, and Anna Piil Damm. 2019. "Refugee Migration and Electoral Outcomes." The Review of Economic Studies 86 (5): 2035-91.

Eberl, Jakob-Moritz, Christine E Meltzer, Tobias Heidenreich, Beatrice Herrero, Nora Theorin, Fabienne Lind, Rosa Berganza, Hajo G Boomgaarden, Christian Schemer, and Jesper Strömbäck. 2018. "The European Media Discourse on Immigration and Its Effects: A Literature Review." 
Annals of the International Communication Association 42 (3): 207-23.

Edo, Anthony, Yvonne Giesing, Jonathan Öztunc, and Panu Poutvaara. 2019. "Immigration and Electoral Support for the Far-Left and the Far-Right." European Economic Review 115: 99-143.

Elsas, Erika van, and Wouter van Der Brug. 2015. “The Changing Relationship between Left-Right Ideology and Euroscepticism, 1973-2010.” European Union Politics 16 (2): 194-215.

Elsas, Erika van, Armen Hakhverdian, and Wouter van der Brug. 2016. "United against a Common Foe? The Nature and Origins of Euroscepticism among Left-Wing and Right-Wing Citizens.” West European Politics 39 (6): 1181-1204.

Enos, Ryan D. 2014. "Causal Effect of Intergroup Contact on Exclusionary Attitudes." Proceedings of the National Academy of Sciences of America 111 (10): 3699-3704.

España-Nájera, Annabella, and David Vera. 2020. “Attitudes Toward Immigration: Ethnicity Trumps Skills But Not Legality?” Social Science Quarterly 101 (2): 545-57.

Evans, Geoffrey, and Jonathan Mellon. 2019. "Immigration, Euroscepticism, and the Rise and Fall of UKIP." Party Politics 25 (1): 76-87.

Evans, Jocelyn, and Gilles Ivaldi. 2020. "Contextual Effects of Immigrant Presence on Populist Radical Right Support: Testing the 'Halo Effect' on Front National Voting in France." Comparative Political Studies 54 (5): 823-54.

Fietkau, Sebastian, and Kasper M Hansen. 2018. "How Perceptions of Immigrants Trigger Feelings of Economic and Cultural Threats in Two Welfare States." European Union Politics 19 (1): 119-39.

Finseraas, Henning, and Andreas Kotsadam. 2017. "Does Personal Contact with Ethnic Minorities Affect Anti-Immigrant Sentiments? Evidence from a Field Experiment." European Journal of Political Research 56: 703-22.

Gessler, Theresa, Gergő Tóth, and Johannes Wachs. 2021. "No Country for Asylum Seekers? How Short-Term Exposure to Refugees Influences Attitudes and Voting Behavior in Hungary." Political Behavior.

Glinitzer, Konstantin, Tobias Gummer, and Markus Wagner. 2021. "Learning Facts About Migration: Politically Motivated Learning of Polarizing Information About Refugees." Political Psychology $\mathrm{n} / \mathrm{a}$ (n/a).

Goodman, Sara Wallace. 2021. "Immigration Threat, Partisanship, and Democratic Citizenship: Evidence from the US, UK, and Germany." Comparative Political Studies, March, 0010414021997165.

Gorodzeisky, Anastasia, and Moshe Semyonov. 2020. "Perceptions and Misperceptions: Actual Size, 
Perceived Size and Opposition to Immigration in European Societies." Journal of Ethnic and Migration Studies 46 (3, SI): 612-30.

Green, Seth, and Donald Green. 2019. “The Contact Hypothesis Re-Evaluated.” Behavioural Public Policy 3 (2): 129-58.

Grigorieff, Alexis, Christopher Roth, and Diego Ubfal. 2020. "Does Information Change Attitudes Toward Immigrants?” Demography 57 (3): 1117-43.

Guriev, Sergei, and Elias Papaioannou. 2020. "The Political Economy of Populism.” Available at SSRN 3542052.

Hainmueler, Jens, and Michael J Hiscox. 2010. "Attitudes toward Highly Skilled and Low-Skilled Immigration: Evidence from a Survey Experiment-Erratum." American Political Science Review 104 (3): 624.

Halikiopoulou, Daphne, Kyriaki Nanou, and Sofia Vasilopoulou. 2012. "The Paradox of Nationalism: The Common Denominator of Radical Right and Radical Left Euroscepticism.” European Journal of Political Research 51 (4): 504-39.

Halikiopoulou, Daphne, and Tim Vlandas. 2020. "When Economic and Cultural Interests Align: The Anti-Immigration Voter Coalitions Driving Far Right Party Success in Europe.” European Political Science Review, 1-22.

Halla, Martin, Alexander F Wagner, and Josef Zweimüller. 2017. "Immigration and Voting for the Far Right." Journal of the European Economic Association 15 (6): 1341-85.

Hangartner, Dominik, Elias Dinas, Moritz Marbach, Konstantinos Matakos, and Dimitrios Xefteris. 2019. "Does Exposure to the Refugee Crisis Make Natives More Hostile?” American Political Science Review 113 (2): 442-55.

Harteveld, Eelco, Joep Schaper, Sarah L De Lange, and Wouter der Brug. 2018. "Blaming Brussels? The Impact of (News about) the Refugee Crisis on Attitudes towards the EU and National Politics." Journal of Common Market Studies 56 (1, SI): 157-77.

Hauwaert, Steven M Van, and Patrick English. 2019. "Responsiveness and the Macro-Origins of Immigration Opinions: Evidence from Belgium, France and the UK." Comparative European Politics 17 (6): 832-59.

Hedegaard, Troels Fage, and Hidde Bekhuis. 2021. "Who Benefits? Perceptions of Which Migrant Groups Benefit the Most from the Welfare State among Ten Migrant Groups in the Netherlands, Denmark, and Germany.” Acta Politica 56 (1): 49-68.

Heerden, Sjoerdje van, and Didier Ruedin. 2017. "How Attitudes towards Immigrants Are Shaped by 
Residential Context: The Role of Ethnic Diversity Dynamics and Immigrant Visibility." Urban Studies 56 (2): 317-34.

Heinisch, Reinhard, Duncan McDonnell, and Annika Werner. 2020. "Equivocal Euroscepticism: How Populist Radical Right Parties Can Have Their EU Cake and Eat It.” Journal of Common Market Studies.

Hix, Simon, Eric Kaufmann, and Thomas J Leeper. 2021. "Pricing Immigration." Journal of Experimental Political Science 8 (1): 63-74.

Hobolt, Sara B, and Catherine E de Vries. 2016. "Public Support for European Integration." Annual Review of Political Science 19 (1): 413-32.

Holbrook, Thomas M, and Aaron C Weinschenk. 2020. "Are Perceptions of Local Conditions Rooted in Reality? Evidence From Two Large-Scale Local Surveys.” American Politics Research 48 (4): 46774.

Homola, Jonathan, and Margits Tavits. 2018. "Contact Reduces Immigration-Related Fears for Leftist but Not for Rightist Voters.” Comparative Political Studies 51 (13): 1789-1820.

Hooghe, Marc, and Thomas de Vroome. 2015. "The Perception of Ethnic Diversity and AntiImmigrant Sentiments: A Multilevel Analysis of Local Communities in Belgium.” Ethnic and Racial Studies 38 (1, SI): 38-56.

Hopkins, Daniel J. 2010. "Politicized Places: Explaining Where and When Immigrants Provoke Local Opposition." American Political Science Review 104 (1): 40-60.

Hopkins, Daniel J, John Sides, and Jack Citrin. 2019. "The Muted Consequences of Correct Information about Immigration.” The Journal of Politics 81 (1): 315-20.

Hoxhaj, Rezart, and Carolina V Zuccotti. 2021. "The Complex Relationship between Immigrants' Concentration, Socioeconomic Environment and Attitudes towards Immigrants in Europe." Ethnic and Racial Studies 44 (2): 44:2, 272-92.

Huijsmans, Twan, Eelco Harteveld, Wouter van der Brug, and Bram Lancee. 2021. "Are Cities Ever More Cosmopolitan? Studying Trends in Urban-Rural Divergence of Cultural Attitudes." Political Geography 86: 102353.

Jeannet, Anne-Marie. 2020a. "A Threat from within? Perceptions of Immigration in an Enlarging European Union.” Acta Sociologica 63 (4): 43-360.

- 2020b. "Internal Migration and Public Opinion about the European Union: A Time Series Cross-Sectional Study." Socio-Economic Review 20 (3): 817-838.

_.2020c. "Immigration and Political Distrust in Europe: A Comparative Longitudinal Study." 
European Societies $22(2):$ 211-30.

Jørgensen, Frederik Juhl, and Mathias Osmundsen. 2020. “Correcting Citizens’ Misperceptions about

Non-Western Immigrants: Corrective Information, Interpretations, and Policy Opinions.” Journal of Experimental Political Science, 1-10.

Kentmen-Cin, Cigdem, and Cengiz Erisen. 2017. "Anti-Immigration Attitudes and the Opposition to European Integration: A Critical Assessment.” European Union Politics 18 (1): 3-25.

Kramer, Dion, Jessica Sampson Thierry, and Franca van Hooren. 2018. "Responding to Free Movement: Quarantining Mobile Union Citizens in European Welfare States.” Journal of European Public Policy 25 (10): 1501-21.

Kros, Mathijs, and Miles Hewstone. 2020. "Negative and Positive Interethnic Contact and the Association of Ethnic Neighbourhood Composition with Trust, Cohesion, and Prejudice." European Sociological Review 36 (6): 937-56.

Kuntz, Anabel, Eldad Davidov, and Moshe Semyonov. 2017. “The Dynamic Relations between Economic Conditions and Anti-Immigrant Sentiment: A Natural Experiment in Times of the European Economic Crisis." International Journal of Comparative Sociology 58 (5): 392-415.

Lonsky, Jakub. 2021. "Does Immigration Decrease Far-Right Popularity? Evidence from Finnish Municipalities." Journal of Population Economics 34 (1): 97-139.

Lutz, Philipp. 2021. “Loved and Feared: Citizens' Ambivalence towards Free Movement in the European Union.” Journal of European Public Policy 28 (2): 268-88.

MacInnis, Cara C, and Elizabeth Page-Gould. 2015. "How Can Intergroup Interaction Be Bad If Intergroup Contact Is Good? Exploring and Reconciling an Apparent Paradox in the Science of Intergroup Relations.” Perspectives on Psychological Science 10 (3): 307-27.

McDonnell, Duncan, and Annika Werner. 2019. "Differently Eurosceptic: Radical Right Populist Parties and Their Supporters." Journal of European Public Policy 26 (12): 1761-78.

McLaren, L M. 2003. "Anti-Immigrant Prejudice in Europe: Contact, Threat Perception, and Preferences for the Exclusion of Migrants." Social Forces 81 (3): 909-36.

McLaren, Lauren, Anja Neundorf, and Ian Paterson. 2021. "Diversity and Perceptions of Immigration: How the Past Influences the Present." Political Studies.

Meleady, Rose, Charles R Seger, and Marieke Vermue. 2017. "Examining the Role of Positive and Negative Intergroup Contact and Anti-Immigrant Prejudice in Brexit.” Psychology 56 (4): 799-808. Meltzer, Christine E, Jakob-Moritz Eberl, Nora Theorin, Tobias Heidenreich, Jesper Strömbäck, Hajo G Boomgaarden, and Christian Schemer. 2020. "Media Effects on Policy Preferences toward 
Free Movement: Evidence from Five EU Member States.” Journal of Ethnic and Migration Studies 0 (0): 1-19.

Ostaijen, Mark van. 2020. "Legitimating Intra-European Movement Discourses: Understanding Mobility and Migration." Comparative European Politics 18 (1): 1-20.

Palma, Paolo A, Vanessa M Sinclair, and Victoria M Esses. 2020. "Facts versus Feelings: Objective and Subjective Experiences of Diversity Differentially Impact Attitudes towards the European Union.” Group Processes \& Intergroup Relations 23 (5): 726-743.

Pettigrew, T F, and L R Tropp. 2006. “A Meta-Analytic Test of Intergroup Contact Theory.” Journal of Personality and Social Psychology 90 (5): 751-83.

- 2008. "How Does Intergroup Contact Reduce Prejudice? Meta-analytic Tests of Three Mediators." European Journal of Social Psychology 38 (6): 922-34.

Pirro, Andrea Lp, Paul Taggart, and Stijn van Kessel. 2018. "The Populist Politics of Euroscepticism in Times of Crisis: Comparative Conclusions.” Politics 38 (3): 378-90.

Posta, Dj Della. 2013. "Competitive Threat, Intergroup Contact, or Both? Immigration and the Dynamics of Front National Voting in France." Social Forces 92 (1): 249-73.

Putnam, Robert D. 2007. "E Pluribus Unum : Diversity and Community in the Twenty-first Century The 2006 Johan Skytte Prize Lecture.” Scandinavian Political Studies 30 (2): 137-74.

Rooduijn, Matthijs, Bart Bonikowski, and Jante Parlevliet. 2021. "Populist and Nativist Attitudes: Does Ingroup-Outgroup Thinking Spill over across Domains?” European Union Politics, February, 1465116521992876.

Roos, Christof. 2019. "The (de-) Politicization of EU Freedom of Movement: Political Parties, Opportunities, and Policy Framing in Germany and the UK." Comparative European Politics 17 (5): $631-50$.

Rydgren, Jens, and Patrick Ruth. 2013. "Contextual Explanations of Radical Right-Wing Support in Sweden: Socioeconomic Marginalization, Group Threat, and the Halo Effect.” Ethnic and Racial Studies 36 (4): 711-28.

Savelkoul, Michael, Joran Laméris, and Jochem Tolsma. 2017. "Neighbourhood Ethnic Composition and Voting for the Radical Right in The Netherlands. The Role of Perceived Neighbourhood Threat and Interethnic Neighbourhood Contact.” European Sociological Review 33 (2): 209-24.

Schaub, Max, Johanna Gereke, and Delia Baldassarri. 2020. "Strangers in Hostile Lands: Exposure to Refugees and Right-Wing Support in Germany's Eastern Regions." Comparative Political Studies 54 (3-4): 686-717. 
Scheepers, Peer, Mrove Gijsberts, and Marcel Coenders. 2002. "Ethnic Exclusionism in European Countries. Public Opposition to Civil Rights for Legal Migrants as a Response to Perceived Ethnic Threat." European Sociological Review 18 (1): 17-34.

Schlüter, E, and P L H Scheepers. 2010. “The Relationship between Outgroup Size and AntiOutgroup Attitudes: A Theoretical Synthesis and Empirical Test of Group Threat- and Intergroup Contact Theory." Social Science Research 39: 285-95.

Schmidt, Susanne K, Michael Blauberger, and Dorte Sindbjerg Martinsen. 2018. "Free Movement and Equal Treatment in an Unequal Union.” Journal of European Public Policy 25 (10): 1391-1402.

Schneider, Silke L. 2008. “Anti-Immigrant Attitudes in Europe: Outgroup Size and Perceived Ethnic Threat." European Sociological Review 24 (1): 53-67.

Semyonov, M, R Raijman, and A Gorodzeisky. 2006. "The Rise of Anti-Foreigner Sentiment in European Societies, 1988-2000." American Sociological Review 71 (3): 426-49.

Sequeira, Sandra, Nathan Nunn, and Nancy Qian. 2017. "Migrants and the Making of America: The Short-and Long-Run Effects of Immigration during the Age of Mass Migration.” NBER Working Papers, no. 23289.

Shehaj, Albana, Adrian J Shin, and Ronald Inglehart. 2019. "Immigration and Right-Wing Populism: An Origin Story.” Party Politics, 135406881984988.

Sipma, Take, and Marcel Lubbers. 2020. "Contextual-Level Unemployment and Support for RadicalRight Parties: A Meta-Analysis.” Acta Politica 55 (3): 351-87.

Stansfield, Richard, and Brenna Stone. 2018. "Threat Perceptions of Migrants in Britain and Support for Policy." Sociological Perspectives 61 (4): 592-609.

Steele, Liza G, and Lamis Abdelaaty. 2019. “Ethnic Diversity and Attitudes towards Refugees.” Journal of Ethnic and Migration Studies 45 (11): 1833-56.

Steinmayr, Andreas. 2020. "Contact versus Exposure: Refugee Presence and Voting for the FarRight." The Review of Economics and Statistics 0 (ja): 1-47.

Stockemer, Daniel. 2016. "Structural Data on Immigration or Immigration Perceptions? What Accounts for the Electoral Success of the Radical Right in Europe?" Journal of Common Market Studies 54 (4): 999-1016.

Stockemer, Daniel, Daphne Halikiopoulou, and Tim Vlandas. 2020. "Birds of a Feather'? Assessing the Prevalence of Anti-Immigration Attitudes among the Far Right Electorate.” Journal of Ethnic and Migration Studies 0 (0): 1-28.

Stockemer, Daniel, Arne Niemann, Johannes Rabenschlag, Johanna Speyer, and Doris Unger. 2018. 
"Immigration, Anti-Immigrant Attitudes and Eurosceptism: A Meta-Analysis." French Politics 16 $(3, \mathrm{SI}): 328-40$.

Tabellini, Marco. 2020. "Gifts of the Immigrants, Woes of the Natives: Lessons from the Age of Mass Migration." The Review of Economic Studies 87 (1): 454-86.

Thomsen, Jens Peter Frølund, and Arzoo Rafiqi. 2019. "Intergroup Contact and Its Right-Wing Ideological Constraint." Journal of Ethnic and Migration Studies 45 (15): 2739-57.

—. 2020. "Ideological Biases Weaken the Impact of Social Trust on Ethnic Outgroup Threat." Political Studies 68 (2): 523-40.

Toshkov, Dimiter. 2018. "Does Immigration Explain the Comeback of the Radical Right in Spain?" EUROPP.

Toshkov, Dimiter, and Elitsa Kortenska. 2015. "Does Immigration Undermine Public Support for Integration in the European Union?” Journal of Common Market Studies 53 (4): 910-25.

Treib, Oliver. 2020. "Exploring Mainstream Euroscepticism: Similarities and Differences between Eurosceptic Claims of Centre-Right and Radical Right Parties.” Research \& Politics 7 (3): 2053168020953301.

Vasilopoulou, Sofia, and Liisa Talving. 2019. “Opportunity or Threat? Public Attitudes towards EU Freedom of Movement." Journal of European Public Policy 26 (6): 805-23.

Viskanic, Max. 2017. "Fear and Loathing on the Campaign Trail: Did Immigration Cause Brexit?" Available at SSRN 2941611.

Vreese, Claes H de, and Hajo G Boomgaarden. 2005. "Projecting EU Referendums: Fear of Immigration and Support for European Integration." European Union Politics 6 (1): 59-82.

Wagner, Ulrich, Oliver Christ, Thomas F Pettigrew, Jost Stellmacher, and Carina Wolf. 2006. "Prejudice And Minority Proportion: Contact Instead Of Threat Effects." Social Psychology Quarterly 69 (4): 380-90.

Wenzel, Michał, and Marta Żerkowska-Balas. 2019. "Framing Effect of Media Portrayal of Migrants to the European Union: A Survey Experiment in Poland." East European Politics \& Societies and Cultures 33 (1): 44-65.

Wijk, Daniël van, Gideon Bolt, and Ron Johnston. 2019. “Contextual Effects on Populist Radical Right Support: Consensual Neighbourhood Effects and the Dutch PVV.” European Sociological Review 35 (2): 225-38.

Wijk, Daniël van, Gideon Bolt, and Jochem Tolsma. 2020. "Where Does Ethnic Concentration Matter for Populist Radical Right Support? An Analysis of Geographical Scale and the Halo Effect.” 
Political Geography 77 (March).

Zhirkov, Kirill. 2021. "Who Are 'the Immigrants'? Beliefs About Immigrant Populations and AntiImmigration Attitudes in the United States and Britain." Social Science Quarterly 102 (1): 228-37.

Ziller, Conrad, and Christoph Spörlein. 2020. "Residential Segregation and Social Trust of Immigrants and Natives: Evidence From the Netherlands ." Frontiers in Sociology . 


\section{Supplementary materials}

\section{Level of analysis and data availability}

Table A1. Level of analysis

\begin{tabular}{|c|c|c|c|}
\hline Country & Locality & Number & Population size \\
\hline the Netherlands & Municipality (gemeentes) & 355 (2019) to 483 (2004) & $\begin{array}{l}\text { min. }=941 ; \text { max. }=844,947 ; \\
\text { med. }=29,731 ; \text { mean }=48,117\end{array}$ \\
\hline Denmark & Municipality (kommuner) & 98 & $\begin{array}{l}\min .=255 ; \text { max. }=130,638 ; \\
\text { med. }=6,482 ; \text { mean }=10,335\end{array}$ \\
\hline Finland & Municipality (kunnista) & 311 (2019) to 303 (2004) & $\begin{array}{l}\min .=91 ; \text { max. }=648,042 ; \\
\text { med. }=6,081 ; \text { mean }=17,742\end{array}$ \\
\hline Sweden & Municipality (kommuner) & 290 & $\begin{array}{l}\min .=2,450 ; \text { max. }=962,154 ; \\
\text { med. }=15,970 ; \text { mean }=35,276\end{array}$ \\
\hline Italy & Municipality (comuni) & 7,915 & $\begin{array}{l}\min .=29 ; \text { max. }=2,872,800 ; \\
\text { med. }=2,480 ; \text { mean }=7,649\end{array}$ \\
\hline Portugal & Municipality (concelho) & 308 & $\begin{array}{l}\min .=465 ; \text { max. }=508,368 ; \\
\text { med. }=13,814 ; \text { mean }=33,397\end{array}$ \\
\hline
\end{tabular}

Table A2. Data availability

Country Elections

\begin{tabular}{ll}
\hline the Netherlands & European Parliament elections (2004, 2009, 2014, 2019); \\
& National Parliament elections (2010, 2012, 2017); Referendum (2016) \\
Denmark & European Parliament elections (2004, 2009, 2014, 2019) \\
Finland & European Parliament elections (2004, 2009, 2014, 2019); \\
& National Parliament elections (2011, 2007, 2011, 2015, 2019) \\
Sweden & European Parliament election (2019) \\
Italy & European Parliament election (2019, 2014); National Parliament election (2018) \\
Portugal & European Parliament election (2019)
\end{tabular}


Table A3. Operationalization of immigration

\begin{tabular}{|c|c|c|c|}
\hline Country & CEE immigration & Alternative CEE & Non-Western immigration \\
\hline the Netherlands & $\mathrm{EU}-(\mathrm{NL}+\mathrm{BE}+\mathrm{DE}+\mathrm{FR}+$ & $\mathrm{HU}+\mathrm{PL}$ & Total born abroad - (EU+ \\
\hline$(2019,2014,2009$, & $\mathrm{EL}+\mathrm{IT}+\mathrm{AU}+\mathrm{PT}+\mathrm{ES}+\mathrm{UK})$ & & Australia + Canada + USA + other \\
\hline 2004) & & & North America) \\
\hline Denmark & EU-11 & $\mathrm{EU}-13+\mathrm{AL}+\mathrm{BH}+$ & Europe outside EU $28+$ Africa + \\
\hline$(2019,2014,2009$, & $(\mathrm{BG}+\mathrm{EE}+\mathrm{HR}+\mathrm{LV}+\mathrm{LT}+\mathrm{PL}+$ & $\mathrm{YU}+\mathrm{SB}+\mathrm{MK}+\mathrm{MD}+$ & South \& Central Americat \\
\hline 2004) & $\mathrm{RO}+\mathrm{SK}+\mathrm{SI}+\mathrm{CZ}+\mathrm{HU})$ & $\mathrm{MN}+\mathrm{UA}+\mathrm{BY}+\mathrm{RU}$ & Asia + Oceania + Stateless \\
\hline Finland & EU-11 & $\mathrm{EU}-13+\mathrm{AL}+\mathrm{BH}+$ & Turkey+Africa+America- \\
\hline$(2018,2014,2009$, & $(\mathrm{BG}+\mathrm{EE}+\mathrm{HR}+\mathrm{LV}+\mathrm{LT}+\mathrm{PL}+$ & $\mathrm{YU}+\mathrm{SB}+\mathrm{MK}+\mathrm{MD}+$ & Canada-US+Asia+Unknown \\
\hline 2004) & $\mathrm{RO}+\mathrm{SK}+\mathrm{SI}+\mathrm{CZ}+\mathrm{HU})$ & $\mathrm{MN}+\mathrm{UA}+\mathrm{BY}+\mathrm{RU}$ & \\
\hline Sweden (2018) & EU28 - Nordic - Germany & PL & Turkey+Africa + Asia + S. Am. \\
\hline Italy & EU-11 & $\mathrm{EU}-13+\mathrm{AL}+\mathrm{BH}+$ & All foreign-Europe-Australia- \\
\hline$(2019,2018,2014$ & $(\mathrm{BG}+\mathrm{EE}+\mathrm{HR}+\mathrm{LV}+\mathrm{LT}+\mathrm{PL}+$ & $\mathrm{XK}+\mathrm{YU}+\mathrm{SB}+\mathrm{MK}+$ & Canada-US-Japan-New Zealand \\
\hline 2004) & $\mathrm{RO}+\mathrm{SK}+\mathrm{SI}+\mathrm{CZ}+\mathrm{HU})$ & $\mathrm{MD}+\mathrm{MN}+\mathrm{UA}+\mathrm{BY}+\mathrm{RU}$ & \\
\hline \multirow[t]{3}{*}{ Portugal (2019) } & $\mathrm{RO}$ & $\mathrm{RO}+\mathrm{MD}+\mathrm{UA}$ & All foreign-Spain-France-UK- \\
\hline & & & Romania-Ukraine-Moldavia- \\
\hline & & & Other European countries \\
\hline
\end{tabular}


Table A4. Classification of political parties

\begin{tabular}{lll} 
Country & Left-wing Eurosceptic parties & Right-wing Eurosceptic parties \\
\hline the Netherlands & SP (2004-2019), 50 PLUS (2019) & FVD (2019), PVV (2009-2019), LPF (2004), \\
& Anti-EU party (2014), Article 50 (2014) \\
Denmark & $\begin{array}{l}\text { Folkbevegelsen mod EU (2004-2019, } \\
\text { Enhedlisten - De Rod - Gronne (2019), }\end{array}$ & Alliance (2009-2019) \\
& June Bevegelsen - Mod Union (2004- & \\
& $2009)$ & \\
Finland & $/$ & True Finns (2004-2019) \\
Sweden & the Left (2019) & Swedish Democrats (2019) \\
Italy & 5 Stars Movement (2019) & Lega (2019), Fratelli d'Italia (2019) \\
Portugal & $/$ & Basta! [with People's Monarchist Party / \\
& & Citizenship \& Christian Democracy] (2019) \\
\hline
\end{tabular}

Table A5. Overview of covariates included in the analyses

\begin{tabular}{ll} 
Country & Covariates \\
\hline The Netherlands & Share of non-Western immigration, Population, Unemployment, Income, Higher education, \\
& Pensioners, Social assistance, Urbanization, Religiosity \\
Denmark & Share of non-Western immigration, Population, Unemployment, Income, Higher education, \\
& Pensioners, Social assistance, Crime \\
Finland & Share of non-Western immigration, Population, Unemployment, Income, Higher education, \\
& Pensioners, Urbanization, Share of Swedish speakers \\
Sweden & Share of non-Western immigration, Population, Income, Higher education, Social assistance, Crime \\
Italy & Share of non-Western immigration, Population, Unemployment (province), Income (region), \\
& Higher education (region), Pensioners (province), Social assistance \\
Portugal & Share of non-Western immigration, Population, Unemployment, Income, Higher education, \\
& Pensioners, Social assistance, Crime
\end{tabular}

In all countries, 'Population' tracks the number of residents in the municipality at 1 January of the latest available year, in million. The rest of the variables are operationalized as follows: 


\section{The Netherlands}

Unemployment: Share of people receiving benefits for being unable to work

Income: Median wealth (balance of assets and liabilities) of private households

Higher education: Share of people with master/doctoraal/Hoger beroepsonderwijs BA degrees

Pensioners: share of people receiving pensions (AOW)

Social assistance: Share of people receiving any social benefits

Crime: NA

Urbanization: Share of people living in urban or very urban areas

Religiosity: Share of the valid votes cast for CU or SGP

\section{Denmark}

Unemployment: Share of people receiving unemployment benefits

Income: Median of family net total wealth

Higher education: Share of people with education H60 and above

Pensioners: share of people receiving national old-age pension

Social assistance: Share of households receiving housing benefits

Crime: Number of all criminal offences per resident

\section{Sweden}

Unemployment: NA

Income: Median of individual earned taxable income, except capital income

Higher education: Share of people with tertiary education

Pensioners: NA

Social assistance: Share of people receiving social benefits

Crime: Total reported crimes per resident

\section{Finland}

Unemployment: Economic dependency ratio

Income: Annual contribution margin per capita

Higher education: Share of people with tertiary education

Pensioners: Share of pensioners of the population

Social assistance: NA 


\section{Crime: NA}

Urbanization: Share of people living in urban settlements

Share of Swedish-speakers: Share of people with Swedish as a mother tongue

\section{Italy}

Unemployment: Share of unemployed (province)

Income: Consumer households' disposable income per inhabitant (region)

Higher education: Share of people with tertiary education (region)

Pensioners: Share of pensioners (province)

Social assistance: Spending of social services per inhabitant

Crime: NA

\section{Portugal}

Unemployment: Share of people registered at the unemployment office (average for the year)

Income: Purchasing power per capita

Higher education: Share of people with higher education

Pensioners: Share of people receiving Social Security and PA Retirement Fund pensions

Social assistance: Share of people receiving Guaranteed Min. Income and Soc. Integr. Benefit

Crime: Crimes registered by police per thousand inhabitants 
Summary of regression model results

Table A6. Right-wing Euroscepticism at EP 2019 in all countries

Multivariate linear regression models of 2019 European Parliament elections

\begin{tabular}{|c|c|c|c|c|c|c|}
\hline & \multicolumn{6}{|c|}{ Vote share of right-wing Eurosceptic parties } \\
\hline & the Netherlands & s Denmark & Sweden & Finland & Italy & Portugal \\
\hline \multirow[t]{2}{*}{ CEE immigrants share (log) } & $0.02^{* * *}$ & 0.002 & $0.05^{* * *}$ & $0.004^{* *}$ & -0.001 & $0.003^{* * *}$ \\
\hline & $(0.003)$ & $(0.01)$ & $(0.005)$ & $(0.001)$ & $(0.002)$ & $(0.0003)$ \\
\hline \multirow[t]{2}{*}{ Non-Western immigrants share (log) } & -0.01 & 0.001 & $-0.02^{* * *}$ & -0.0002 & $0.005^{* * *}$ & $0.002^{* *}$ \\
\hline & $(0.01)$ & $(0.01)$ & $(0.01)$ & $(0.002)$ & $(0.001)$ & $(0.001)$ \\
\hline \multirow[t]{2}{*}{ Population } & $-0.08^{* *}$ & 0.02 & -0.04 & $-0.14^{* * *}$ & $-0.18^{* * *}$ & -0.01 \\
\hline & $(0.04)$ & $(0.06)$ & $(0.04)$ & $(0.04)$ & $(0.03)$ & $(0.01)$ \\
\hline \multirow[t]{2}{*}{ Unemployment } & $0.93^{* *}$ & 0.16 & & $-0.0002^{*}$ & $-0.01^{* * *}$ & 0.01 \\
\hline & $(0.40)$ & $(0.18)$ & & $(0.0001)$ & $(0.0004)$ & $(0.03)$ \\
\hline \multirow[t]{2}{*}{ Income } & -0.07 & 0.00 & $-0.0003^{* *}$ & $-0.03^{* * *}$ & $0.02^{* * *}$ & 0.07 \\
\hline & $(0.04)$ & $(0.00)$ & $(0.0001)$ & $(0.01)$ & $(0.001)$ & $(0.05)$ \\
\hline \multirow[t]{2}{*}{ ‘Higher education` } & $-4.35^{* * *}$ & $-0.62^{* * *}$ & $-0.73^{* * *}$ & $-0.002^{* * *}$ & 0.15 & -0.02 \\
\hline & $(0.73)$ & $(0.13)$ & $(0.08)$ & $(0.001)$ & $(0.09)$ & $(0.02)$ \\
\hline \multirow[t]{2}{*}{ Pensioners } & -0.16 & -0.03 & & $-0.001^{*}$ & $0.15^{* * *}$ & $-0.001^{* * *}$ \\
\hline & $(0.27)$ & $(0.11)$ & & $(0.001)$ & $(0.05)$ & $(0.0005)$ \\
\hline \multirow[t]{2}{*}{ 'Social assistance` } & 0.11 & -0.07 & 0.35 & & $-0.20^{* * *}$ & $0.01^{* * *}$ \\
\hline & $(0.26)$ & $(0.17)$ & $(0.32)$ & & $(0.01)$ & $(0.002)$ \\
\hline \multirow[t]{2}{*}{ Urbanization } & 0.02 & & & 0.0000 & & \\
\hline & $(0.01)$ & & & $(0.0001)$ & & \\
\hline \multirow[t]{2}{*}{ Religiosity } & -0.02 & & & & & \\
\hline & $(0.02)$ & & & & & \\
\hline \multirow[t]{2}{*}{ Crime } & & $1.14^{* *}$ & 0.05 & & & $-0.17^{* * *}$ \\
\hline & & $(0.45)$ & $(0.10)$ & & & $(0.05)$ \\
\hline \multirow[t]{2}{*}{ ‘Share of Swedish speakers` } & & & & $-0.002^{* * *}$ & & \\
\hline & & & & $(0.0001)$ & & \\
\hline \multirow[t]{2}{*}{ Constant } & $0.20^{* * *}$ & $0.16^{* * *}$ & $0.46^{* * *}$ & $0.33^{* * *}$ & $0.21^{* * *}$ & $0.05^{* * *}$ \\
\hline & $(0.03)$ & $(0.04)$ & $(0.05)$ & $(0.03)$ & $(0.02)$ & $(0.01)$ \\
\hline Observations & 354 & 98 & 285 & 295 & 7,395 & 308 \\
\hline $\mathrm{R}^{2}$ & 0.31 & 0.47 & 0.57 & 0.70 & 0.42 & 0.31 \\
\hline Adjusted $\mathrm{R}^{2}$ & 0.29 & 0.41 & 0.56 & 0.69 & 0.42 & 0.29 \\
\hline
\end{tabular}

Notes: Unit of analysis is municipality.

${ }^{*} \mathrm{p}<0.1 ;{ }^{* *} \mathrm{p}<0.05 ;{ }^{* * *} \mathrm{p}<0.01$ 
Table A7. Left-wing Euroscepticism at EP 2019 in all countries

Multivariate linear regression models of 2019 European Parliament elections

\begin{tabular}{|c|c|c|c|c|}
\hline & \multicolumn{4}{|c|}{ Vote share of left-wing Eurosceptic parties } \\
\hline & the Netherlands & Denmark & Sweden & Italy \\
\hline \multirow[t]{2}{*}{ CEE immigrants share (log) } & $0.01^{* * *}$ & $-0.01^{* *}$ & $-0.02^{* * *}$ & $-0.01^{* * *}$ \\
\hline & $(0.002)$ & $(0.004)$ & $(0.002)$ & $(0.001)$ \\
\hline \multirow[t]{2}{*}{ Non-Western immigrants share (log) } & $-0.02^{* * *}$ & $0.02^{* * *}$ & 0.0001 & $0.002^{* *}$ \\
\hline & $(0.005)$ & $(0.01)$ & $(0.004)$ & $(0.001)$ \\
\hline \multirow[t]{2}{*}{ Population } & $-0.09^{* * *}$ & 0.01 & $0.07^{* * *}$ & $0.06^{* * *}$ \\
\hline & $(0.02)$ & $(0.04)$ & $(0.02)$ & $(0.01)$ \\
\hline \multirow[t]{2}{*}{ Unemployment } & -0.24 & $0.39^{* * *}$ & & $0.003^{* * *}$ \\
\hline & $(0.26)$ & $(0.11)$ & & $(0.0002)$ \\
\hline \multirow[t]{2}{*}{ Income } & -0.01 & $-0.0000^{* * *}$ & -0.0000 & $-0.02^{* * *}$ \\
\hline & $(0.03)$ & $(0.00)$ & $(0.0001)$ & $(0.0004)$ \\
\hline \multirow[t]{2}{*}{ ‘Higher education` } & $-1.36^{* * *}$ & $0.20^{* *}$ & 0.02 & $0.68^{* * *}$ \\
\hline & $(0.48)$ & $(0.08)$ & $(0.04)$ & $(0.05)$ \\
\hline \multirow[t]{2}{*}{ Pensioners } & $-0.86^{* * *}$ & $0.20^{* * *}$ & & -0.02 \\
\hline & $(0.18)$ & $(0.07)$ & & $(0.02)$ \\
\hline \multirow[t]{2}{*}{ 'Social assistance` } & $0.71^{* * *}$ & 0.04 & $0.33^{* *}$ & $-0.02^{* * *}$ \\
\hline & $(0.17)$ & $(0.10)$ & $(0.17)$ & $(0.005)$ \\
\hline \multirow[t]{2}{*}{ Urbanization } & 0.004 & & & \\
\hline & $(0.01)$ & & & \\
\hline \multirow[t]{2}{*}{ Religiosity } & $-0.12^{* * *}$ & & & \\
\hline & $(0.01)$ & & & \\
\hline \multirow[t]{2}{*}{ Crime } & & 0.02 & $0.18^{* * *}$ & \\
\hline & & $(0.28)$ & $(0.05)$ & \\
\hline \multirow[t]{2}{*}{ Constant } & $0.09^{* * *}$ & $0.05^{*}$ & -0.04 & $0.39^{* * *}$ \\
\hline & $(0.02)$ & $(0.03)$ & $(0.03)$ & $(0.01)$ \\
\hline Observations & 354 & 98 & 285 & 7,395 \\
\hline $\mathrm{R}^{2}$ & 0.44 & 0.63 & 0.33 & 0.66 \\
\hline Adjusted R² & 0.42 & 0.59 & 0.31 & 0.66 \\
\hline
\end{tabular}

Notes: Unit of analysis is municipality.

${ }^{*} \mathrm{p}<0.1 ;{ }^{* *} \mathrm{p}<0.05 ;{ }^{* * *} \mathrm{p}<0.01$ 
Table A8. Euroscepticism at EP 2019 in all countries: Replication with population covariates only

Linear regression models of 2019 European Parliament elections

\begin{tabular}{lccccccc}
\hline & \multicolumn{5}{c}{ Vote share of right-wing Eurosceptic parties } \\
\cline { 2 - 7 } & the Netherlands Denmark Sweden Finland & Italy & Portugal \\
\hline CEE immigrants share (log) & $0.02^{* * *}$ & $0.02^{* *}$ & $0.02^{* * *}$ & $0.01^{* * *}$ & $0.01^{* * *}$ & $0.002^{* * *}$ \\
& $(0.003)$ & $(0.01)$ & $(0.01)$ & $(0.001)$ & $(0.002)$ & $(0.0003)$ \\
Non-Western immigrants share (log) & 0.01 & $-0.01^{*}$ & 0.001 & -0.002 & $0.04^{* * *}$ & 0.001 \\
& $(0.005)$ & $(0.01)$ & $(0.01)$ & $(0.002)$ & $(0.002)$ & $(0.001)$ \\
Population & $-0.11^{* * *}$ & $-0.13^{* * *}$ & $-0.28^{* * *}$ & $-0.19^{* * *}$ & $-0.33^{* * *}$ & -0.003 \\
& $(0.03)$ & $(0.05)$ & $(0.04)$ & $(0.04)$ & $(0.03)$ & $(0.01)$ \\
'Share of Swedish speakers & & & & $-0.002^{* * *}$ & & \\
Constant & & & & $(0.0001)$ & & \\
& $0.25^{* * *}$ & $0.19^{* * *}$ & $0.30^{* * *}$ & $0.20^{* * *}$ & $0.67^{* * *}$ & $0.04^{* * *}$ \\
& $(0.02)$ & $(0.03)$ & $(0.02)$ & $(0.01)$ & $(0.01)$ & $(0.003)$ \\
\hline Observations & 354 & 99 & 287 & 295 & 7,839 & 308 \\
$\mathrm{R}^{2}$ & 0.09 & 0.14 & 0.17 & 0.65 & 0.10 & 0.22 \\
Adjusted R ${ }^{2}$ & 0.08 & 0.11 & 0.16 & 0.65 & 0.10 & 0.21 \\
\hline Notes: Unit of analysis is municipality. & & ${ }^{*} \mathrm{p}<0.1 ;{ }^{* *} \mathrm{p}<0.05 ; *^{* * *} \mathrm{p}<0.01$ & &
\end{tabular}

Linear regression models of 2019 European Parliament elections

\begin{tabular}{lcccc}
\hline & \multicolumn{3}{c}{ Vote share of left-wing Eurosceptic parties } \\
\cline { 2 - 5 } & the Netherlands & Denmark Sweden & Italy \\
\hline CEE immigrants share $(\log )$ & $0.01^{* * *}$ & $-0.02^{* * *}$ & $-0.02^{* * *}$ & $-0.01^{* * *}$ \\
& $(0.002)$ & $(0.01)$ & $(0.002)$ & $(0.001)$ \\
Non-Western immigrants share $(\log )$ & -0.002 & $0.02^{* * *}$ & $0.01^{* * *}$ & $-0.03^{* * *}$ \\
& $(0.003)$ & $(0.005)$ & $(0.003)$ & $(0.001)$ \\
Population & $-0.05^{*}$ & 0.03 & $0.09^{* * *}$ & $0.16^{* * *}$ \\
& $(0.03)$ & $(0.03)$ & $(0.02)$ & $(0.02)$ \\
Constant & $0.14^{* * *}$ & $0.08^{* * *}$ & -0.001 & -0.01 \\
& $(0.01)$ & $(0.02)$ & $(0.01)$ & $(0.01)$ \\
\hline Observations & 354 & 99 & 287 & 7,839 \\
$\mathrm{R}^{2}$ & 0.11 & 0.23 & 0.28 & 0.13 \\
Adjusted R & 0.10 & 0.20 & 0.27 & 0.13 \\
\hline Notes: Unit of anasis is municipality & ${ }^{*} \mathrm{p}<0.1 *^{* *} \mathrm{p}<0.05 \cdot^{* * *} \mathrm{p}<0.01$ &
\end{tabular}

Notes: Unit of analysis is municipality. $\quad{ }^{*} \mathrm{p}<0.1 ;{ }^{* *} \mathrm{p}<0.05 ;{ }^{* * *} \mathrm{p}<0.01$ 
Table A9. Right-wing Euroscepticism at EP 2019 in all countries: Replication with vote shares from all eligible voters Multivariate linear regression models of 2019 European Parliament elections

\begin{tabular}{|c|c|c|c|c|c|c|}
\hline & \multicolumn{6}{|c|}{ Vote share from eligible voters of right-wing Eurosceptic parties } \\
\hline & the Netherlands & Denmark & Sweden & Finland & Italy & Portugal \\
\hline \multirow[t]{2}{*}{ CEE immigrants share (log) } & $0.004^{* * *}$ & -0.0003 & $0.02^{* * *}$ & $0.002^{* * *}$ & 0.001 & $0.001^{* * *}$ \\
\hline & $(0.001)$ & $(0.004)$ & $(0.003)$ & $(0.001)$ & $(0.001)$ & $(0.0001)$ \\
\hline \multirow[t]{2}{*}{ Non-Western immigrants share (log) } & 0.003 & 0.001 & $-0.01^{* * *}$ & -0.001 & $0.01^{* * *}$ & $0.0004^{*}$ \\
\hline & $(0.002)$ & $(0.01)$ & $(0.004)$ & $(0.001)$ & $(0.001)$ & $(0.0002)$ \\
\hline \multirow[t]{2}{*}{ Population } & $-0.02^{*}$ & 0.002 & -0.02 & $-0.05^{* *}$ & $-0.12^{* * *}$ & 0.001 \\
\hline & $(0.01)$ & $(0.04)$ & $(0.02)$ & $(0.02)$ & $(0.02)$ & $(0.003)$ \\
\hline \multirow[t]{2}{*}{ Unemployment } & $0.35^{\text {** }}$ & 0.02 & & $-0.0001^{* *}$ & $-0.004^{* * *}$ & -0.004 \\
\hline & $(0.14)$ & $(0.11)$ & & $(0.0001)$ & $(0.0003)$ & $(0.01)$ \\
\hline \multirow[t]{2}{*}{ Income } & -0.02 & $0.00^{*}$ & -0.0001 & $-0.01^{* * *}$ & $0.02^{* * *}$ & 0.01 \\
\hline & $(0.02)$ & $(0.00)$ & $(0.0001)$ & $(0.003)$ & $(0.001)$ & $(0.01)$ \\
\hline \multirow[t]{2}{*}{ ‘Higher education` } & $-1.23^{* * *}$ & $-0.33^{* * *}$ & $-0.25^{* * *}$ & -0.0001 & $0.23^{* * *}$ & -0.001 \\
\hline & $(0.27)$ & $(0.08)$ & $(0.04)$ & $(0.0002)$ & $(0.07)$ & $(0.01)$ \\
\hline \multirow[t]{2}{*}{ Pensioners } & $0.31^{* * *}$ & -0.05 & & -0.0002 & 0.01 & 0.0001 \\
\hline & $(0.10)$ & $(0.07)$ & & $(0.0002)$ & $(0.03)$ & $(0.0001)$ \\
\hline \multirow[t]{2}{*}{ 'Social assistance' } & $-0.26^{* * *}$ & -0.11 & 0.13 & & $-0.18^{* * *}$ & $0.001^{* *}$ \\
\hline & $(0.09)$ & $(0.10)$ & $(0.17)$ & & $(0.01)$ & $(0.0005)$ \\
\hline \multirow[t]{2}{*}{ Urbanization } & 0.01 & & & $-0.0001^{*}$ & & \\
\hline & $(0.004)$ & & & $(0.0001)$ & & \\
\hline \multirow[t]{2}{*}{ Religiosity } & 0.01 & & & & & \\
\hline & $(0.01)$ & & & & & \\
\hline \multirow[t]{2}{*}{ Crime } & & $0.51^{*}$ & -0.07 & & & $-0.06^{* * *}$ \\
\hline & & $(0.27)$ & $(0.05)$ & & & $(0.01)$ \\
\hline \multirow[t]{2}{*}{ ‘Share of Swedish speakers` } & & & & $-0.001^{* * *}$ & & \\
\hline & & & & $(0.0000)$ & & \\
\hline \multirow[t]{2}{*}{ Constant } & $0.09^{* * *}$ & $0.11^{* * *}$ & $0.21^{* * *}$ & $0.12^{* * *}$ & $0.03^{*}$ & $0.01^{* * *}$ \\
\hline & $(0.01)$ & $(0.03)$ & $(0.03)$ & $(0.01)$ & $(0.02)$ & $(0.001)$ \\
\hline Observations & 354 & 98 & 285 & 310 & 7,395 & 308 \\
\hline $\mathrm{R}^{2}$ & 0.19 & 0.37 & 0.43 & 0.63 & 0.56 & 0.27 \\
\hline Adjusted R ${ }^{2}$ & 0.16 & 0.30 & 0.41 & 0.62 & 0.55 & 0.25 \\
\hline
\end{tabular}


Table A10. Right-wing Euroscepticism at EP 2019 in all countries: Replication with alternative CEE measure

Multivariate linear regression models of 2019 European Parliament elections

\begin{tabular}{|c|c|c|c|c|c|c|}
\hline & \multicolumn{6}{|c|}{ Vote share of right-wing Eurosceptic parties } \\
\hline & the Netherlands & Denmark & Sweden & Finland & Italy & Portugal \\
\hline \multirow[t]{2}{*}{ Alternative CEE immigrants share (log) } & $0.01^{* * *}$ & 0.004 & $0.03^{* * *}$ & 0.001 & -0.001 & $0.003^{* * *}$ \\
\hline & $(0.002)$ & $(0.01)$ & $(0.003)$ & $(0.002)$ & $(0.002)$ & $(0.0004)$ \\
\hline \multirow[t]{2}{*}{ Non-Western immigrants share (log) } & -0.01 & -0.0003 & $-0.02^{* * *}$ & 0.0001 & $0.005^{* * *}$ & 0.001 \\
\hline & $(0.01)$ & $(0.01)$ & $(0.01)$ & $(0.002)$ & $(0.001)$ & $(0.001)$ \\
\hline \multirow[t]{2}{*}{ Population } & $-0.07^{* *}$ & 0.02 & -0.04 & $-0.13^{* * *}$ & $-0.18^{* * *}$ & -0.01 \\
\hline & $(0.04)$ & $(0.06)$ & $(0.04)$ & $(0.04)$ & $(0.03)$ & $(0.01)$ \\
\hline \multirow[t]{2}{*}{ Unemployment } & $0.74^{*}$ & 0.17 & & $-0.0004^{* * *}$ & $-0.01^{* * *}$ & -0.004 \\
\hline & $(0.40)$ & $(0.18)$ & & $(0.0001)$ & $(0.0004)$ & $(0.03)$ \\
\hline \multirow[t]{2}{*}{ Income } & -0.07 & 0.00 & $-0.0003^{* *}$ & $-0.03^{* * *}$ & $0.02^{* * *}$ & 0.05 \\
\hline & $(0.04)$ & $(0.00)$ & $(0.0001)$ & $(0.01)$ & $(0.001)$ & $(0.05)$ \\
\hline \multirow[t]{2}{*}{ ‘Higher education` } & $-3.96^{* * *}$ & $-0.62^{* * *}$ & $-0.68^{* * *}$ & $-0.002^{* * *}$ & 0.15 & -0.02 \\
\hline & $(0.74)$ & $(0.13)$ & $(0.08)$ & $(0.001)$ & $(0.09)$ & $(0.02)$ \\
\hline \multirow[t]{2}{*}{ Pensioners } & -0.21 & -0.03 & & -0.001 & $0.15^{* * *}$ & $-0.001^{* *}$ \\
\hline & $(0.27)$ & $(0.11)$ & & $(0.001)$ & $(0.05)$ & $(0.0005)$ \\
\hline \multirow[t]{2}{*}{ 'Social assistance' } & 0.18 & -0.07 & 0.45 & & $-0.20^{* * *}$ & $0.01^{* * *}$ \\
\hline & $(0.26)$ & $(0.16)$ & $(0.30)$ & & $(0.01)$ & $(0.002)$ \\
\hline \multirow[t]{2}{*}{ Urbanization } & 0.02 & & & 0.0000 & & \\
\hline & $(0.01)$ & & & $(0.0001)$ & & \\
\hline \multirow[t]{2}{*}{ Religiosity } & -0.03 & & & & & \\
\hline & $(0.02)$ & & & & & \\
\hline \multirow[t]{2}{*}{ Crime } & & $1.11^{* *}$ & 0.07 & & & $-0.15^{* * *}$ \\
\hline & & $(0.45)$ & $(0.10)$ & & & $(0.05)$ \\
\hline \multirow[t]{2}{*}{ 'Share of Swedish speakers` } & & & & $-0.002^{* * *}$ & & \\
\hline & & & & $(0.0001)$ & & \\
\hline \multirow[t]{2}{*}{ Constant } & $0.19^{* * *}$ & $0.16^{* * *}$ & $0.44^{* * *}$ & $0.33^{* * *}$ & $0.22^{* * *}$ & $0.05^{* * *}$ \\
\hline & $(0.03)$ & $(0.04)$ & $(0.05)$ & $(0.03)$ & $(0.02)$ & $(0.01)$ \\
\hline Observations & 354 & 98 & 283 & 295 & 7,395 & 308 \\
\hline $\mathrm{R}^{2}$ & 0.31 & 0.47 & 0.60 & 0.70 & 0.42 & 0.29 \\
\hline Adjusted $\mathrm{R}^{2}$ & 0.29 & 0.41 & 0.59 & 0.69 & 0.42 & 0.27 \\
\hline
\end{tabular}

Notes: Unit of analysis is municipality. 
Table A11. Right-wing Euroscepticism at EP 2019 in all countries: Replication with changes in immigration presence Multivariate linear regression models of 2019 European Parliament elections

\begin{tabular}{|c|c|c|c|c|c|c|c|}
\hline & \multicolumn{7}{|c|}{ Vote share of Eurosceptic parties } \\
\hline & $\begin{array}{l}\text { the Netherlands } \\
\text { right wing }\end{array}$ & $\begin{array}{l}\text { the Netherlands } \\
\text { left wing }\end{array}$ & $\begin{array}{l}\text { Denmark } \\
\text { right wing }\end{array}$ & $\begin{array}{l}\text { Denmark } \\
\text { left wing }\end{array}$ & Finland & $\begin{array}{l}\text { Italy right } \\
\text { wing }\end{array}$ & $\begin{array}{l}\text { Italy left } \\
\text { wing }\end{array}$ \\
\hline \multirow[t]{2}{*}{$\begin{array}{l}\text { Change in CEE } \\
\text { immigrants share }\end{array}$} & $1.04^{* * *}$ & $0.73^{* * *}$ & 0.29 & $-0.60^{* *}$ & -0.05 & -0.04 & $-0.15^{* * *}$ \\
\hline & $(0.19)$ & $(0.13)$ & $(0.41)$ & $(0.26)$ & $(0.23)$ & $(0.08)$ & $(0.04)$ \\
\hline \multirow[t]{2}{*}{$\begin{array}{l}\text { Change in non-Western } \\
\text { immigrants share }\end{array}$} & $0.82^{* * *}$ & 0.08 & 0.001 & 0.07 & -0.12 & $-0.27^{* * *}$ & $0.07^{* *}$ \\
\hline & $(0.21)$ & $(0.15)$ & $(0.25)$ & $(0.16)$ & $(0.28)$ & $(0.07)$ & $(0.03)$ \\
\hline \multirow[t]{2}{*}{ Population } & $-0.09^{* * *}$ & $-0.10^{* * *}$ & 0.02 & -0.02 & $-0.11^{* *}$ & $-0.16^{* * *}$ & $0.06^{* * *}$ \\
\hline & $(0.03)$ & $(0.02)$ & $(0.06)$ & $(0.04)$ & $(0.05)$ & $(0.03)$ & $(0.01)$ \\
\hline \multirow[t]{2}{*}{ Unemployment } & $3.54^{* * *}$ & -1.16 & 0.14 & $0.61^{* * *}$ & $\stackrel{-}{-}^{*} 0004^{* * *}$ & $-0.01^{* * *}$ & $0.003^{* * *}$ \\
\hline & $(1.31)$ & $(0.90)$ & $(0.17)$ & $(0.11)$ & $(0.0001)$ & $(0.0004)$ & $(0.0002)$ \\
\hline \multirow[t]{2}{*}{ Income } & -0.09 & $-0.08^{* *}$ & 0.00 & $-0.0000^{* * *}$ & $\begin{array}{c}- \\
0.0000^{* * *}\end{array}$ & $0.02^{* * *}$ & $-0.02^{* * *}$ \\
\hline & $(0.06)$ & $(0.04)$ & $(0.00)$ & $(0.00)$ & $(0.0000)$ & $(0.001)$ & $(0.0004)$ \\
\hline \multirow[t]{2}{*}{ 'Higher education' } & $-4.42^{* * *}$ & $-1.26^{* *}$ & $-0.60^{* * *}$ & $0.23^{* *}$ & $-0.003^{* * *}$ & $2.11^{* *}$ & $6.20^{* * *}$ \\
\hline & $(0.73)$ & $(0.50)$ & $(0.14)$ & $(0.09)$ & $(0.001)$ & $(0.93)$ & $(0.48)$ \\
\hline \multirow[t]{2}{*}{ Pensioners } & $-0.69^{* * *}$ & $-0.66^{* * *}$ & -0.02 & 0.06 & -0.001 & $0.14^{* * *}$ & -0.03 \\
\hline & $(0.14)$ & $(0.10)$ & $(0.09)$ & $(0.06)$ & $(0.001)$ & $(0.05)$ & $(0.02)$ \\
\hline \multirow[t]{2}{*}{ 'Social assistance' } & $0.64^{* * *}$ & $0.53^{* * *}$ & -0.05 & $0.19^{* *}$ & & $-0.21^{* * *}$ & $-0.02^{* * *}$ \\
\hline & $(0.11)$ & $(0.08)$ & $(0.14)$ & $(0.09)$ & & $(0.01)$ & $(0.005)$ \\
\hline \multirow[t]{2}{*}{ Urbanization } & 0.005 & $-0.01^{* *}$ & & & 0.0001 & & \\
\hline & $(0.01)$ & $(0.01)$ & & & $(0.0001)$ & & \\
\hline \multirow[t]{2}{*}{ Religiosity } & -0.02 & $-0.11^{* * *}$ & & & & & \\
\hline & $(0.02)$ & $(0.01)$ & & & & & \\
\hline \multirow[t]{2}{*}{ Crime } & & & $1.13^{* * *}$ & 0.33 & & & \\
\hline & & & $(0.43)$ & $(0.27)$ & & & \\
\hline \multirow[t]{2}{*}{ Swedish speakers } & & & & & $-0.002^{* * *}$ & & \\
\hline & & & & & $(0.0001)$ & & \\
\hline \multirow[t]{2}{*}{ Constant } & $0.13^{* * *}$ & $0.08^{* * *}$ & $0.14^{* * *}$ & 0.03 & $0.33^{* * *}$ & $0.20^{* * *}$ & $0.41^{* * *}$ \\
\hline & $(0.02)$ & $(0.02)$ & $(0.03)$ & $(0.02)$ & $(0.02)$ & $(0.02)$ & $(0.01)$ \\
\hline Observations & 354 & 354 & 98 & 98 & 287 & 7,184 & 7,184 \\
\hline $\mathrm{R}^{2}$ & 0.32 & 0.39 & 0.47 & 0.60 & 0.69 & 0.42 & 0.66 \\
\hline Adjusted $\mathrm{R}^{2}$ & 0.30 & 0.38 & 0.41 & 0.56 & 0.68 & 0.42 & 0.66 \\
\hline
\end{tabular}

Notes: Unit of analysis is municipality.

${ }^{*} \mathrm{p}<0.1 ;{ }^{* *} \mathrm{p}<0.05 ;{ }^{* * *} \mathrm{p}<0.01$ 
Table A12. The Netherlands over time: EP elections

Multivariate linear regression models of EP elections in the Netherlands, 2004-2019

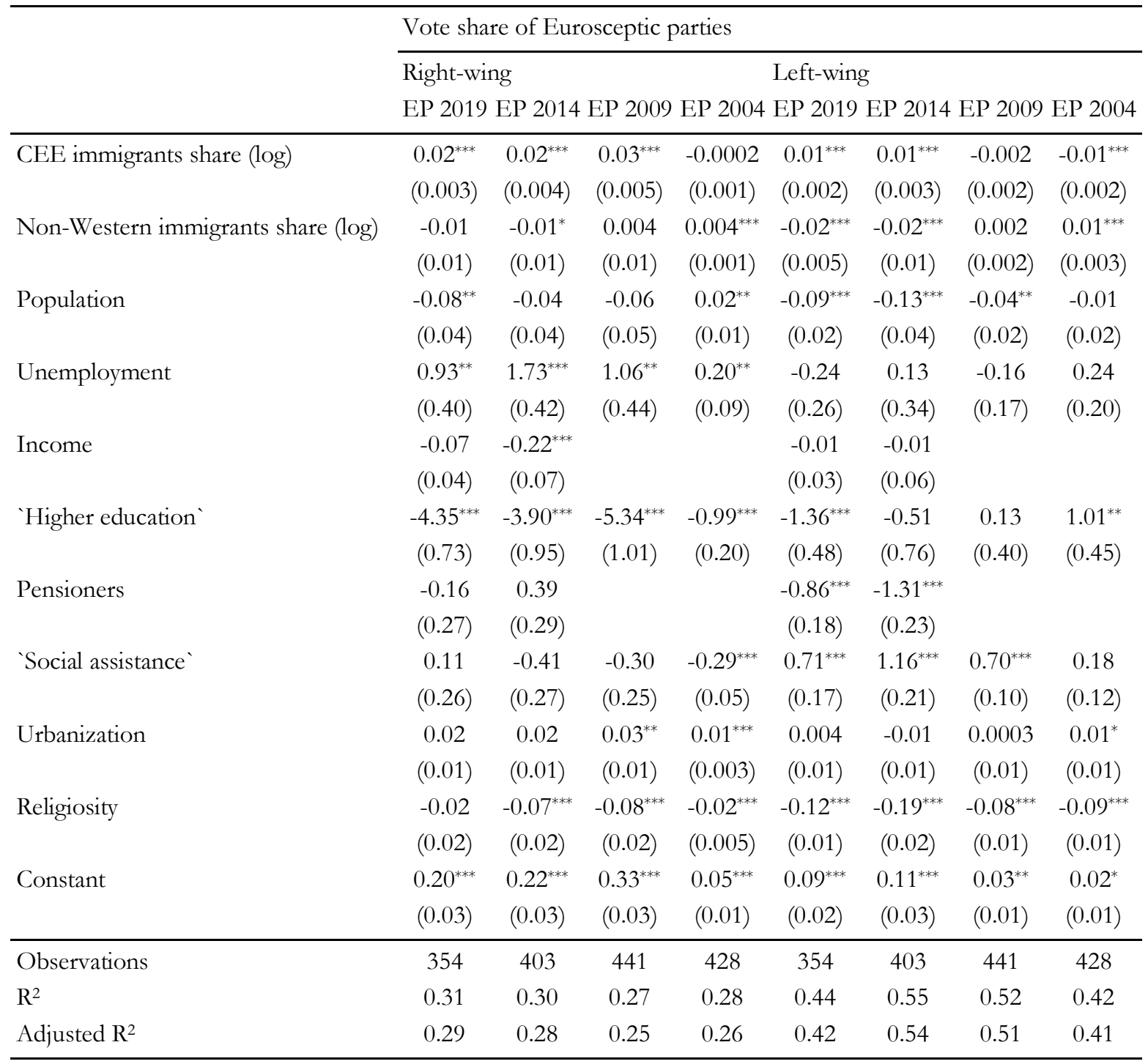

Notes: Unit of analysis is municipality. ${ }^{*} \mathrm{p}<0.1 ;{ }^{* *} \mathrm{p}<0.05 ;{ }^{* * *} \mathrm{p}<0.01$ 
Table A13. The Netherlands over time: national elections

Multivariate linear regression models of Eurosceptic voting at national elections and referenda in The Netherlands

\begin{tabular}{|c|c|c|c|c|c|c|c|c|c|}
\hline & \multicolumn{9}{|c|}{ Vote share of Eurosceptic parties/outcomes } \\
\hline & \multicolumn{4}{|c|}{ Right-wing } & \multirow{2}{*}{$\begin{array}{l}\text { Vote } \\
\text { Against } \\
\text { REF } 2016\end{array}$} & \multicolumn{4}{|c|}{ Left-wing } \\
\hline & $\begin{array}{c}\mathrm{EP} \\
2019\end{array}$ & $\begin{array}{l}\text { NP } \\
2017\end{array}$ & $\begin{array}{l}\mathrm{NP} \\
2012\end{array}$ & $\begin{array}{l}\mathrm{NP} \\
2010\end{array}$ & & $\begin{array}{c}\text { EP } \\
2019\end{array}$ & $\begin{array}{l}\text { NP } \\
2017\end{array}$ & $\begin{array}{l}\text { NP } \\
2012\end{array}$ & $\begin{array}{l}\mathrm{NP} \\
2010\end{array}$ \\
\hline \multirow[t]{2}{*}{ CEE immigrants share (log) } & $0.02^{* * *}$ & $0.02^{* * *}$ & $0.02^{* * *}$ & $0.02^{* * *}$ & $0.03^{* * *}$ & $0.01^{* * *}$ & $0.01^{* *}$ & $0.01^{* * *}$ & -0.002 \\
\hline & $(0.003)$ & $(0.003)$ & $(0.003)$ & $(0.005)$ & $(0.005)$ & $(0.002)$ & $(0.002)$ & $(0.003)$ & $(0.003)$ \\
\hline \multirow[t]{2}{*}{$\begin{array}{l}\text { Non-Western immigrants share } \\
(\log )\end{array}$} & -0.01 & $-0.02^{* * *}$ & $-0.01^{* *}$ & $-0.02^{* * *}$ & $-0.03^{* * *}$ & $-0.02^{* * *}$ & $-0.03^{* * *}$ & $-0.01^{* * *}$ & $-0.01^{* * *}$ \\
\hline & $(0.01)$ & $(0.01)$ & $(0.01)$ & $(0.01)$ & $(0.01)$ & $(0.005)$ & $(0.005)$ & $(0.005)$ & $(0.004)$ \\
\hline \multirow[t]{2}{*}{ Population } & $-0.08^{* *}$ & -0.03 & -0.02 & $-0.08^{*}$ & $-0.11^{*}$ & $-0.09^{* * *}$ & $-0.09^{* * *}$ & $-0.07^{* *}$ & $-0.08^{* * *}$ \\
\hline & $(0.04)$ & $(0.04)$ & $(0.03)$ & $(0.05)$ & $(0.06)$ & $(0.02)$ & $(0.03)$ & $(0.03)$ & $(0.03)$ \\
\hline \multirow[t]{2}{*}{ Unemployment } & $0.93^{* *}$ & $1.61^{* * *}$ & $1.52^{* * *}$ & $0.78^{*}$ & $3.08^{* * * *}$ & -0.24 & 0.14 & $0.71^{* *}$ & -0.39 \\
\hline & $(0.40)$ & $(0.38)$ & $(0.32)$ & $(0.46)$ & $(0.64)$ & $(0.26)$ & $(0.28)$ & $(0.29)$ & $(0.26)$ \\
\hline \multirow[t]{2}{*}{ Income } & -0.07 & $-0.26^{* * *}$ & $-0.17^{* * *}$ & & $-0.47^{* * *}$ & -0.01 & $-0.12^{* * *}$ & 0.07 & \\
\hline & $(0.04)$ & $(0.06)$ & $(0.06)$ & & $(0.10)$ & $(0.03)$ & $(0.04)$ & $(0.05)$ & \\
\hline \multirow[t]{2}{*}{ 'Higher education` } & $-4.35^{* * *}$ & $-2.75^{* * *}$ & $-1.55^{* *}$ & $-3.10^{* * *}$ & $-9.51^{* * *}$ & $-1.36^{* * *}$ & -0.27 & $1.25^{*}$ & -0.04 \\
\hline & $(0.73)$ & $(0.72)$ & $(0.73)$ & $(1.05)$ & $(1.19)$ & $(0.48)$ & $(0.52)$ & $(0.66)$ & $(0.60)$ \\
\hline \multirow[t]{2}{*}{ Pensioners } & -0.16 & 0.32 & 0.27 & & $0.95^{* *}$ & $-0.86^{* * *}$ & $-1.37^{* * *}$ & $-0.94^{* * *}$ & \\
\hline & $(0.27)$ & $(0.28)$ & $(0.22)$ & & $(0.48)$ & $(0.18)$ & $(0.21)$ & $(0.20)$ & \\
\hline \multirow[t]{2}{*}{ 'Social assistance` } & 0.11 & -0.28 & -0.25 & $0.61^{* *}$ & $-1.37^{* * *}$ & $0.71^{* * *}$ & $1.38^{* * *}$ & $0.80^{* * *}$ & $1.09^{* * *}$ \\
\hline & $(0.26)$ & $(0.26)$ & $(0.20)$ & $(0.27)$ & $(0.44)$ & $(0.17)$ & $(0.19)$ & $(0.19)$ & $(0.16)$ \\
\hline \multirow[t]{2}{*}{ Urbanization } & 0.02 & 0.01 & 0.01 & $0.03^{* *}$ & 0.03 & 0.004 & $-0.03^{* * *}$ & -0.01 & -0.003 \\
\hline & $(0.01)$ & $(0.01)$ & $(0.01)$ & $(0.01)$ & $(0.02)$ & $(0.01)$ & $(0.01)$ & $(0.01)$ & $(0.01)$ \\
\hline \multirow[t]{2}{*}{ Religiosity } & -0.02 & $-0.07^{* * *}$ & $-0.06^{* * *}$ & $-0.07^{* *}$ & & $-0.12^{* * *}$ & $-0.19^{* * *}$ & $-0.20^{* * *}$ & $-0.17^{* * *}$ \\
\hline & $(0.02)$ & $(0.02)$ & $(0.02)$ & $(0.03)$ & & $(0.01)$ & $(0.02)$ & $(0.02)$ & $(0.02)$ \\
\hline \multirow[t]{2}{*}{ Constant } & $0.20^{* * *}$ & $0.17^{* * *}$ & $0.11^{* * *}$ & $0.16^{* * *}$ & $0.81^{* * *}$ & $0.09^{* * *}$ & -0.01 & $0.05^{*}$ & -0.003 \\
\hline & $(0.03)$ & $(0.03)$ & $(0.03)$ & $(0.03)$ & $(0.05)$ & $(0.02)$ & $(0.02)$ & $(0.02)$ & $(0.02)$ \\
\hline Observations & 354 & 388 & 403 & 427 & 388 & 354 & 388 & 403 & 427 \\
\hline $\mathrm{R}^{2}$ & 0.31 & 0.38 & 0.30 & 0.28 & 0.38 & 0.44 & 0.69 & 0.55 & 0.48 \\
\hline Adjusted $\mathrm{R}^{2}$ & 0.29 & 0.36 & 0.28 & 0.26 & 0.36 & 0.42 & 0.68 & 0.54 & 0.47 \\
\hline
\end{tabular}


Table A14. Denmark over time: EP elections

Multivariate linear regression models of EP elections in Denmark, 2004-2019

\begin{tabular}{|c|c|c|c|c|c|c|c|c|}
\hline & \multicolumn{8}{|c|}{ Vote share of Eurosceptic parties } \\
\hline & \multicolumn{4}{|c|}{ Right-wing } & \multicolumn{4}{|c|}{ Left-wing } \\
\hline & EP 2019 & EP 2014 & EP 2009 & EP 2004 & EP 2019 & EP 2014 & EP 2009 & EP 2004 \\
\hline \multirow[t]{2}{*}{ CEE immigrants share (log) } & 0.002 & 0.01 & -0.01 & -0.001 & $-0.01^{* *}$ & $-0.01^{* * *}$ & $-0.01^{*}$ & -0.004 \\
\hline & $(0.01)$ & $(0.01)$ & $(0.01)$ & $(0.003)$ & $(0.004)$ & $(0.004)$ & $(0.01)$ & $(0.01)$ \\
\hline \multirow[t]{2}{*}{ Non-Western immigrants share (log) } & 0.001 & $0.02^{* *}$ & $0.03^{* * *}$ & $0.01^{* * *}$ & $0.02^{* * *}$ & 0.01 & 0.01 & 0.01 \\
\hline & $(0.01)$ & $(0.01)$ & $(0.01)$ & $(0.003)$ & $(0.01)$ & $(0.01)$ & $(0.01)$ & $(0.01)$ \\
\hline \multirow[t]{2}{*}{ Population } & 0.02 & -0.004 & $-0.12^{* *}$ & $-0.09^{* * *}$ & 0.01 & 0.01 & -0.03 & -0.03 \\
\hline & $(0.06)$ & $(0.07)$ & $(0.05)$ & $(0.02)$ & $(0.04)$ & $(0.04)$ & $(0.05)$ & $(0.06)$ \\
\hline \multirow[t]{2}{*}{ Unemployment } & 0.16 & $0.45^{* *}$ & 0.08 & $0.16^{* * * *}$ & $0.39^{* * *}$ & $0.21^{* *}$ & 0.20 & $0.59^{* * *}$ \\
\hline & $(0.18)$ & $(0.19)$ & $(0.15)$ & $(0.04)$ & (0.11) & $(0.10)$ & $(0.14)$ & $(0.11)$ \\
\hline \multirow[t]{2}{*}{ Income } & 0.00 & 0.00 & & & $-0.0000^{* * *}$ & $-0.0000^{* * *}$ & & \\
\hline & $(0.00)$ & $(0.00)$ & & & $(0.00)$ & $(0.00)$ & & \\
\hline \multirow[t]{2}{*}{ 'Higher education` } & $-0.62^{* * *}$ & $-1.20^{* * *}$ & $-0.53^{* * *}$ & $-0.25^{* * *}$ & $0.20^{* *}$ & $0.25^{* * *}$ & $0.14^{*}$ & $-0.23^{* *}$ \\
\hline & $(0.13)$ & $(0.15)$ & $(0.09)$ & $(0.04)$ & $(0.08)$ & $(0.08)$ & $(0.08)$ & $(0.11)$ \\
\hline \multirow[t]{2}{*}{ Pensioners } & -0.03 & 0.04 & & & $0.20^{* * *}$ & $0.16^{* *}$ & & \\
\hline & $(0.11)$ & $(0.13)$ & & & $(0.07)$ & $(0.07)$ & & \\
\hline \multirow[t]{2}{*}{ 'Social assistance` } & -0.07 & -0.21 & $-0.31^{* *}$ & $-0.14^{* *}$ & 0.04 & 0.10 & $0.35^{* *}$ & 0.18 \\
\hline & $(0.17)$ & $(0.21)$ & $(0.15)$ & $(0.06)$ & $(0.10)$ & $(0.11)$ & $(0.14)$ & $(0.16)$ \\
\hline \multirow[t]{2}{*}{ Crime } & $1.14^{* *}$ & $0.80^{*}$ & $1.25^{* *}$ & $0.68^{* *}$ & 0.02 & 0.25 & 0.66 & -0.11 \\
\hline & $(0.45)$ & $(0.47)$ & $(0.54)$ & $(0.30)$ & $(0.28)$ & $(0.26)$ & $(0.50)$ & $(0.77)$ \\
\hline \multirow[t]{2}{*}{ Constant } & $0.16^{* * *}$ & $0.41^{* * *}$ & $0.22^{* * *}$ & $0.10^{* * *}$ & $0.05^{*}$ & 0.01 & -0.01 & $0.09^{*}$ \\
\hline & $(0.04)$ & $(0.05)$ & $(0.04)$ & $(0.02)$ & $(0.03)$ & $(0.03)$ & $(0.04)$ & $(0.05)$ \\
\hline Observations & 98 & 98 & 98 & 98 & 98 & 98 & 98 & 98 \\
\hline $\mathrm{R}^{2}$ & 0.47 & 0.69 & 0.52 & 0.53 & 0.63 & 0.55 & 0.29 & 0.31 \\
\hline Adjusted $\mathrm{R}^{2}$ & 0.41 & 0.65 & 0.48 & 0.50 & 0.59 & 0.50 & 0.24 & 0.26 \\
\hline
\end{tabular}

Notes: Unit of analysis is municipality.

${ }^{*} \mathrm{p}<0.1 ;{ }^{* *} \mathrm{p}<0.05 ;{ }^{* * *} \mathrm{p}<0.01$ 
Table A15. Finland over time: EP elections

Multivariate linear regression models of EP elections in Finland, 2004-2019

\begin{tabular}{|c|c|c|c|c|}
\hline & \multicolumn{4}{|c|}{ Vote share of Eurosceptic parties } \\
\hline & \multicolumn{4}{|c|}{ Right-wing } \\
\hline & EP 2019 & EP 2014 & EP 2009 & EP 2004 \\
\hline \multirow[t]{2}{*}{ CEE immigrants share (log) } & $0.004^{* *}$ & $0.003^{* *}$ & -0.001 & 0.0002 \\
\hline & $(0.001)$ & $(0.002)$ & $(0.001)$ & $(0.0003)$ \\
\hline \multirow[t]{2}{*}{ Non-Western immigrants share (log) } & -0.0002 & -0.001 & 0.001 & 0.0000 \\
\hline & $(0.002)$ & $(0.002)$ & $(0.001)$ & $(0.0003)$ \\
\hline \multirow[t]{2}{*}{ Population } & $-0.14^{* * *}$ & $-0.10^{*}$ & -0.04 & 0.01 \\
\hline & $(0.04)$ & $(0.05)$ & $(0.04)$ & $(0.01)$ \\
\hline \multirow[t]{2}{*}{ Unemployment } & $-0.0002^{*}$ & -0.0000 & -0.0001 & -0.0000 \\
\hline & $(0.0001)$ & $(0.0001)$ & $(0.0001)$ & $(0.0000)$ \\
\hline \multirow[t]{2}{*}{ Income } & $-0.03^{* * *}$ & -0.004 & -0.001 & \\
\hline & $(0.01)$ & $(0.01)$ & $(0.01)$ & \\
\hline \multirow[t]{2}{*}{ ‘Higher education` } & $-0.002^{* * *}$ & -0.001 & -0.001 & $-0.0002^{* *}$ \\
\hline & $(0.001)$ & $(0.001)$ & $(0.0004)$ & $(0.0001)$ \\
\hline \multirow[t]{2}{*}{ Pensioners } & $-0.001^{*}$ & $-0.001^{*}$ & 0.0003 & 0.0001 \\
\hline & $(0.001)$ & $(0.001)$ & $(0.0004)$ & $(0.0001)$ \\
\hline \multirow[t]{2}{*}{ Urbanization } & 0.0000 & 0.0001 & 0.0000 & -0.0000 \\
\hline & $(0.0001)$ & $(0.0002)$ & $(0.0001)$ & $(0.0000)$ \\
\hline \multirow[t]{2}{*}{ ‘Share of Swedish speakers` } & $-0.002^{* * *}$ & $-0.002^{* * *}$ & $-0.001^{* * *}$ & $-0.0000^{* *}$ \\
\hline & $(0.0001)$ & $(0.0001)$ & $(0.0001)$ & $(0.0000)$ \\
\hline \multirow[t]{2}{*}{ Constant } & $0.33^{* * *}$ & $0.21^{* * *}$ & $0.14^{* * *}$ & $0.01^{* *}$ \\
\hline & $(0.03)$ & $(0.03)$ & $(0.02)$ & $(0.01)$ \\
\hline Observations & 295 & 305 & 300 & 284 \\
\hline $\mathrm{R}^{2}$ & 0.70 & 0.53 & 0.55 & 0.08 \\
\hline Adjusted $\mathrm{R}^{2}$ & 0.69 & 0.51 & 0.54 & 0.05 \\
\hline
\end{tabular}

Notes: Unit of analysis is municipality. $\quad{ }^{*} \mathrm{p}<0.1 ;{ }^{* *} \mathrm{p}<0.05 ;{ }^{* * *} \mathrm{p}<0.01$ 
Table A15. Finland over time: national elections

Multivariate linear regression models of Eurosceptic voting at national elections and referenda in Finland

\begin{tabular}{|c|c|c|c|c|c|}
\hline & \multicolumn{5}{|c|}{ Vote share of Eurosceptic parties/outcomes } \\
\hline & \multicolumn{5}{|c|}{ Right-wing } \\
\hline & EP 2019 & NP 2019 & NP 2015 & NP 2011 & NP 2007 \\
\hline \multirow[t]{2}{*}{ CEE immigrants share (log) } & $0.004^{* *}$ & $0.005^{* * *}$ & $0.01^{* *}$ & 0.001 & 0.003 \\
\hline & $(0.001)$ & $(0.002)$ & $(0.002)$ & $(0.002)$ & $(0.002)$ \\
\hline \multirow[t]{2}{*}{ Non-Western immigrants share (log) } & -0.0002 & -0.0003 & $0.01^{* *}$ & $0.004^{*}$ & 0.002 \\
\hline & $(0.002)$ & $(0.002)$ & $(0.003)$ & $(0.003)$ & $(0.002)$ \\
\hline \multirow[t]{2}{*}{ Population } & $-0.14^{* * *}$ & $-0.12^{* *}$ & $-0.16^{* *}$ & -0.11 & -0.002 \\
\hline & $(0.04)$ & $(0.05)$ & $(0.07)$ & $(0.08)$ & $(0.07)$ \\
\hline \multirow[t]{2}{*}{ Unemployment } & $-0.0002^{*}$ & -0.0002 & -0.0002 & -0.0002 & -0.0001 \\
\hline & $(0.0001)$ & $(0.0002)$ & $(0.0002)$ & $(0.0002)$ & $(0.0002)$ \\
\hline \multirow[t]{2}{*}{ Income } & $-0.03^{* * *}$ & $-0.02^{* *}$ & $-0.03^{* * *}$ & -0.02 & 0.01 \\
\hline & $(0.01)$ & $(0.01)$ & $(0.01)$ & $(0.01)$ & $(0.01)$ \\
\hline \multirow[t]{2}{*}{ ‘Higher education` } & $-0.002^{* * *}$ & $-0.003^{* * *}$ & $-0.002^{* *}$ & $-0.002^{* *}$ & $-0.002^{* *}$ \\
\hline & $(0.001)$ & $(0.001)$ & $(0.001)$ & $(0.001)$ & $(0.001)$ \\
\hline \multirow[t]{2}{*}{ Pensioners } & $-0.001^{*}$ & $-0.002^{* * *}$ & -0.001 & -0.001 & -0.001 \\
\hline & $(0.001)$ & $(0.001)$ & $(0.001)$ & $(0.001)$ & $(0.001)$ \\
\hline \multirow[t]{2}{*}{ Urbanization } & 0.0000 & 0.0000 & -0.0002 & $-0.0004^{*}$ & $-0.0004^{*}$ \\
\hline & $(0.0001)$ & $(0.0002)$ & $(0.0003)$ & $(0.0002)$ & $(0.0002)$ \\
\hline \multirow[t]{2}{*}{ `Share of Swedish speakers` } & $-0.002^{* * *}$ & $-0.002^{* * *}$ & $-0.002^{* * *}$ & $-0.002^{* * *}$ & $-0.0005^{* * *}$ \\
\hline & $(0.0001)$ & $(0.0001)$ & $(0.0002)$ & $(0.0002)$ & $(0.0002)$ \\
\hline \multirow[t]{2}{*}{ Constant } & $0.33^{* * *}$ & $0.41^{* * *}$ & $0.40^{* * *}$ & $0.40^{* * *}$ & $0.19^{* * *}$ \\
\hline & $(0.03)$ & $(0.03)$ & $(0.04)$ & $(0.05)$ & $(0.04)$ \\
\hline Observations & 295 & 295 & 295 & 295 & 288 \\
\hline $\mathrm{R}^{2}$ & 0.70 & 0.55 & 0.37 & 0.41 & 0.08 \\
\hline Adjusted R² & 0.69 & 0.54 & 0.35 & 0.39 & 0.05 \\
\hline
\end{tabular}

Notes: Unit of analysis is municipality.

${ }^{*} \mathrm{p}<0.1 ;{ }^{* *} \mathrm{p}<0.05 ;{ }^{* *} \mathrm{p}<0.01$ 
Table A17. Italy over time

Multivariate linear regression models of Eurosceptic voting in Italy

\begin{tabular}{|c|c|c|c|c|c|c|}
\hline & \multicolumn{6}{|c|}{ Vote share of Eurosceptic parties } \\
\hline & \multicolumn{3}{|c|}{ Right-wing } & \multicolumn{3}{|c|}{ Left-wing } \\
\hline & EP 2019 & EP 2014 & NP 2018 & EP 2019 & EP 2014 & NP 2018 \\
\hline \multirow[t]{2}{*}{ CEE immigrants share (log) } & -0.001 & $-0.02^{* * *}$ & $-0.01^{* * *}$ & $-0.01^{* * *}$ & $0.01^{* * *}$ & $-0.002^{* *}$ \\
\hline & $(0.002)$ & $(0.002)$ & $(0.001)$ & $(0.001)$ & $(0.002)$ & $(0.001)$ \\
\hline \multirow[t]{2}{*}{ Non-Western immigrants share (log) } & $0.005^{* * *}$ & $0.01^{* * *}$ & $0.002^{* *}$ & $0.002^{* *}$ & $0.01^{* * *}$ & $0.004^{* * *}$ \\
\hline & $(0.001)$ & $(0.002)$ & $(0.001)$ & $(0.001)$ & $(0.002)$ & $(0.001)$ \\
\hline \multirow[t]{2}{*}{ Population } & $-0.18^{* * *}$ & $-0.14^{* * *}$ & $-0.03^{* * *}$ & $0.06^{* * *}$ & $0.17^{* * *}$ & -0.002 \\
\hline & $(0.03)$ & $(0.03)$ & $(0.01)$ & $(0.01)$ & $(0.03)$ & $(0.01)$ \\
\hline \multirow[t]{2}{*}{ Unemployment } & $-0.01^{* * *}$ & $-0.01^{* * *}$ & $-0.005^{* * *}$ & $0.003^{* * *}$ & $0.005^{* * *}$ & $0.01^{* * *}$ \\
\hline & $(0.0004)$ & $(0.001)$ & $(0.0003)$ & $(0.0002)$ & $(0.0005)$ & $(0.0003)$ \\
\hline \multirow[t]{2}{*}{ Income } & $0.02^{* * *}$ & $0.02^{* * *}$ & $0.02^{* * *}$ & $-0.02^{* * *}$ & $-0.01^{* * *}$ & $-0.02^{* * *}$ \\
\hline & $(0.001)$ & $(0.001)$ & $(0.001)$ & $(0.0004)$ & $(0.001)$ & $(0.0005)$ \\
\hline \multirow[t]{2}{*}{ ‘Higher education` } & 0.15 & $-1.01^{* * *}$ & $-0.21^{* * *}$ & $0.68^{* * *}$ & $-0.21^{* *}$ & $0.22^{* * *}$ \\
\hline & $(0.09)$ & $(0.10)$ & $(0.04)$ & $(0.05)$ & $(0.10)$ & $(0.04)$ \\
\hline \multirow[t]{2}{*}{ Pensioners } & $0.15^{* * *}$ & -0.05 & $0.22^{* * *}$ & -0.02 & $0.34^{* * *}$ & $-0.19^{* * *}$ \\
\hline & $(0.05)$ & $(0.04)$ & $(0.02)$ & $(0.02)$ & $(0.04)$ & $(0.01)$ \\
\hline \multirow[t]{2}{*}{ 'Social assistance` } & $-0.20^{* * *}$ & $-0.24^{* * *}$ & $-0.12^{* * *}$ & $-0.02^{* * *}$ & 0.01 & $-0.04^{* * *}$ \\
\hline & $(0.01)$ & $(0.01)$ & $(0.01)$ & $(0.005)$ & $(0.01)$ & $(0.01)$ \\
\hline \multirow[t]{2}{*}{ Constant } & $0.21^{* * *}$ & 0.01 & $-0.14^{* * *}$ & $0.39^{* * *}$ & $0.45^{* * *}$ & $0.56^{* * *}$ \\
\hline & $(0.02)$ & $(0.03)$ & $(0.02)$ & $(0.01)$ & $(0.02)$ & $(0.02)$ \\
\hline Observations & 7,395 & 7,037 & 7,302 & 7,395 & 7,037 & 7,302 \\
\hline $\mathrm{R}^{2}$ & 0.42 & 0.44 & 0.63 & 0.66 & 0.10 & 0.63 \\
\hline Adjusted R² & 0.42 & 0.44 & 0.63 & 0.66 & 0.10 & 0.63 \\
\hline
\end{tabular}

Notes: Unit of analysis is municipality.

${ }^{*} \mathrm{p}<0.1 ;{ }^{* *} \mathrm{p}<0.05 ;{ }^{* * *} \mathrm{p}<0.01$ 
Table A18. Italy over time: Fratelli d'Italia only

Multivariate linear regression models of Eurosceptic voting in Italy

\begin{tabular}{|c|c|c|c|}
\hline & \multirow{2}{*}{\multicolumn{3}{|c|}{$\frac{\text { Vote share of Eurosceptic parties }}{\text { Fratelli d'Italia vote share }}$}} \\
\hline & & & \\
\hline & EP 2019 & \multirow{2}{*}{$\frac{\mathrm{EP} 2014}{0.01^{* * *}}$} & NP 2018 \\
\hline \multirow[t]{2}{*}{ CEE immigrants share (log) } & $0.001^{* *}$ & & $0.003^{* * *}$ \\
\hline & (0.001) & (0.001) & $(0.0003)$ \\
\hline \multirow[t]{2}{*}{ Non-Western immigrants share (log) } & 0.001 & -0.0001 & -0.0000 \\
\hline & $(0.001)$ & $(0.001)$ & $(0.0003)$ \\
\hline \multirow[t]{2}{*}{ Population } & -0.005 & -0.01 & $0.01^{* * *}$ \\
\hline & $(0.01)$ & $(0.02)$ & $(0.002)$ \\
\hline \multirow[t]{2}{*}{ Unemployment } & $0.0003^{*}$ & $-0.002^{* * *}$ & $-0.001^{* * *}$ \\
\hline & $(0.0002)$ & $(0.0002)$ & $(0.0001)$ \\
\hline \multirow[t]{2}{*}{ Income } & $-0.004^{* * *}$ & $-0.01^{* * *}$ & $-0.001^{* * *}$ \\
\hline & $(0.0003)$ & $(0.0004)$ & $(0.0002)$ \\
\hline \multirow[t]{2}{*}{ ‘Higher education` } & $0.25^{* * *}$ & $0.37^{* * *}$ & $-0.14^{* * *}$ \\
\hline & $(0.03)$ & $(0.05)$ & $(0.01)$ \\
\hline \multirow[t]{2}{*}{ Pensioners } & 0.03 & -0.03 & 0.01 \\
\hline & $(0.02)$ & $(0.02)$ & $(0.005)$ \\
\hline \multirow[t]{2}{*}{ 'Social assistance`' } & $-0.02^{* * *}$ & $-0.03^{* * *}$ & $-0.01^{* * *}$ \\
\hline & $(0.003)$ & $(0.01)$ & $(0.002)$ \\
\hline \multirow[t]{2}{*}{ Constant } & $0.10^{* * *}$ & $0.23^{* * *}$ & $0.10^{* * *}$ \\
\hline & $(0.01)$ & $(0.01)$ & $(0.005)$ \\
\hline Observations & 7,395 & 7,037 & 7,302 \\
\hline $\mathrm{R}^{2}$ & 0.10 & 0.07 & 0.04 \\
\hline Adjusted $\mathrm{R}^{2}$ & 0.10 & 0.07 & 0.04 \\
\hline
\end{tabular}

Notes: Unit of analysis is municipality. $\quad{ }^{*} \mathrm{p}<0.1 ;{ }^{* *} \mathrm{p}<0.05 ;{ }^{* * *} \mathrm{p}<0.01$ 